\title{
طاقة الرياح في مصر - دراسة في المناخ التطبيقي
}

د ا إيملي محمد حلمي حمادة

أستاذ الجغرافيا الطبيعية المساعد

كلية الآداب - جامعة المنوفية

ملخص البحث :

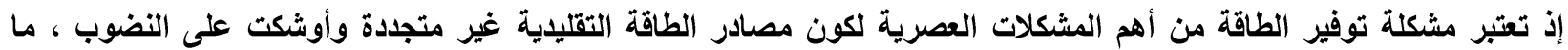

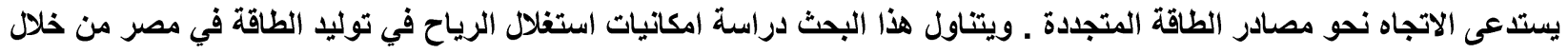

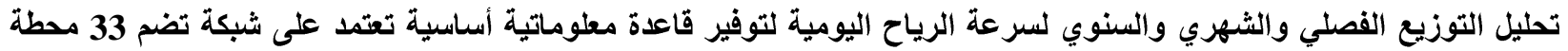

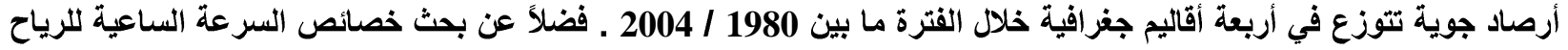

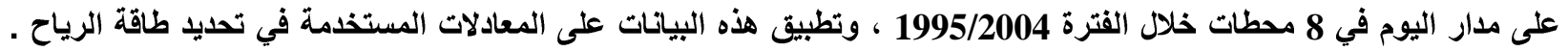

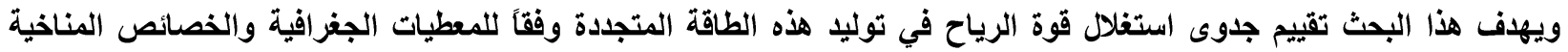

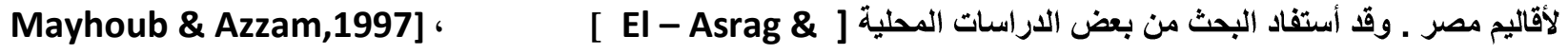

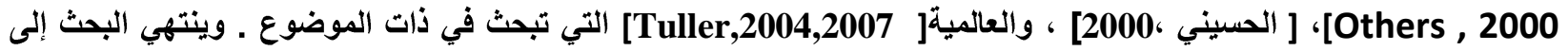
عدد من النتائج التي تؤكد على الامكانيات الواعدة لطاقة الرياح في الساحل الثرقي والساحل الشمالي وصعيد مصر ـ ـ ويوصي البحث

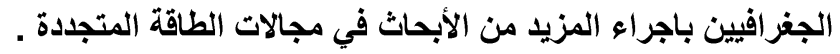

مقدمة :

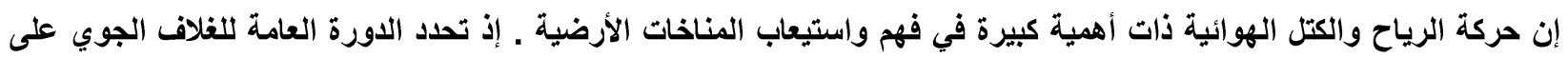

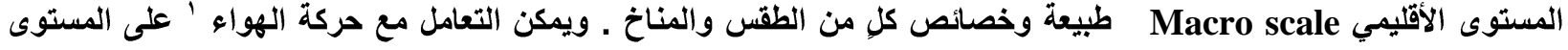
Renewable التفيلي Micro scale هذه Energy

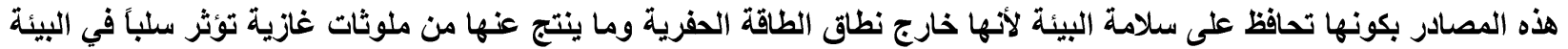

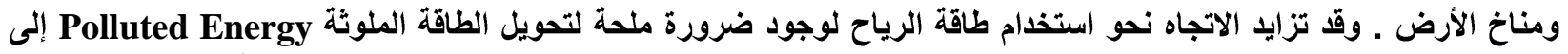

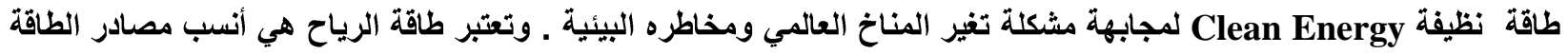

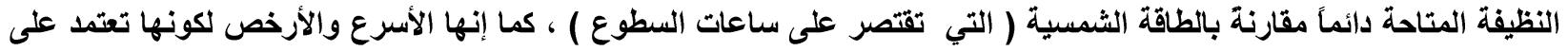

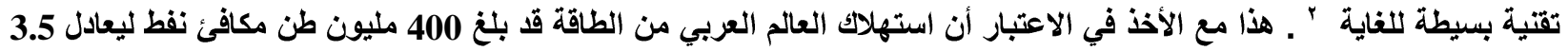

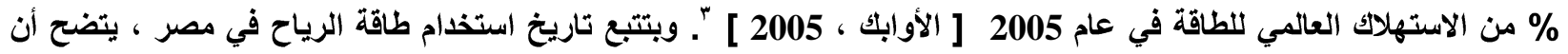

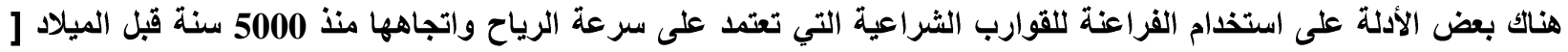

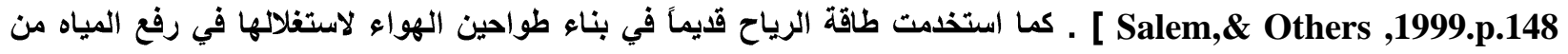

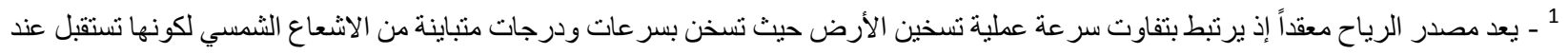

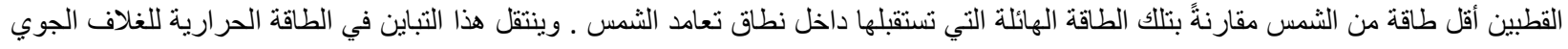

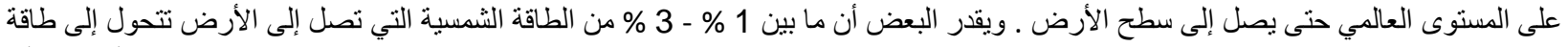

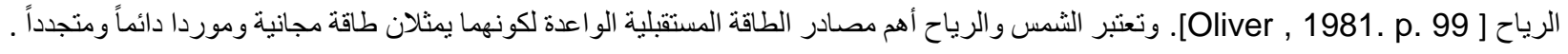

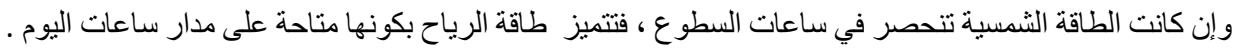

2 ـ تعد تكلفة انتاج الكهرباء من طاقة الرياح هي الأقل مقارنةً بغير ها من مصادر الطاقة المتجددة الأخرى ، إذ تتراوح التكلفة بين 3 - 4 سنت لكل كيلووات ساعة . تئرة 3 ـ قد أعلنت هيئة المجلس العالمي لطاقة الرياح Global Wind Energy Council أن الطاقة الاجمالية للرياح قد بلغت 74.197 ميجاو ات عام 2006

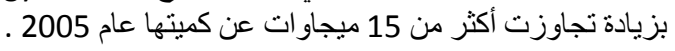


الأبار لتوفير مياه الثرب والري [ الحسيني ، 2000 ـ ص 23 ] ـ ؛ " وقد بلغت قدرات محطات توليد طاقة الرياح من الرياح 145

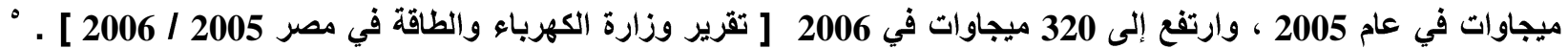

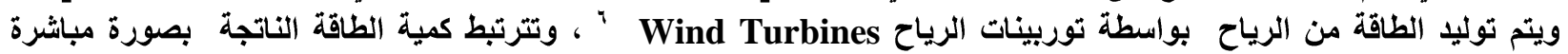

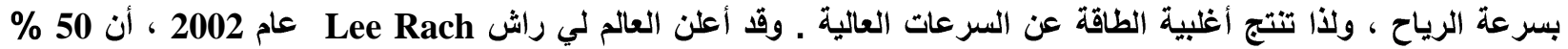
الطاقة الناتجة يتحقق خلال 15 \% فقط من مدة تثغيل توربينات الرياح [ [David , M. , 1999.p42]. وإذ تتميز سرعة الرياح

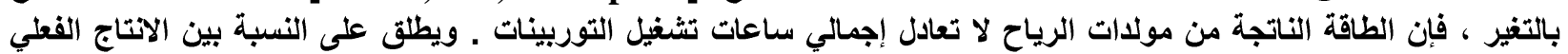

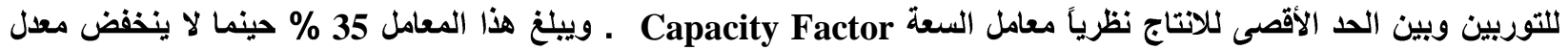

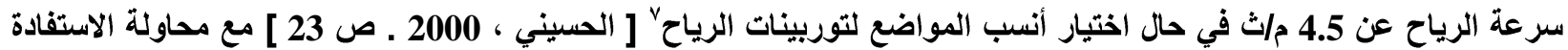

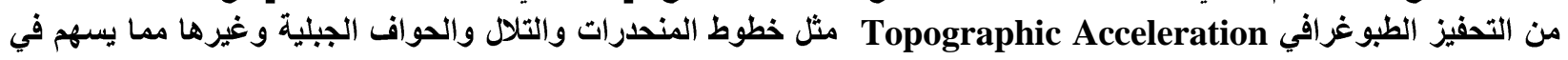
زيادة سرعة الرياح وبالتالي كمية الطاقة المنتجة [ David,\& Others,2001.p 137 ]

يتناول هذا البحث دراسة امكانيات استغلال الرياح في توليد الطاقة في مصر ـ وإذ تعتمد الطاقة المحتملة من الرياح على سرعة الرياحة

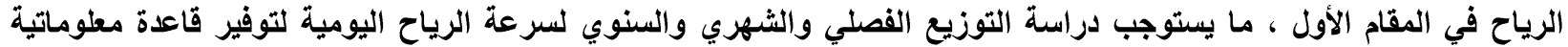

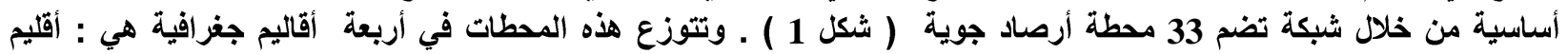

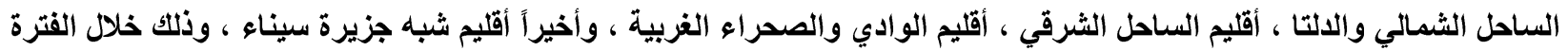

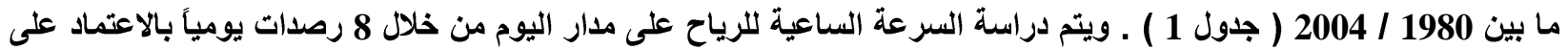

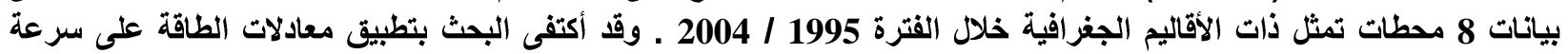

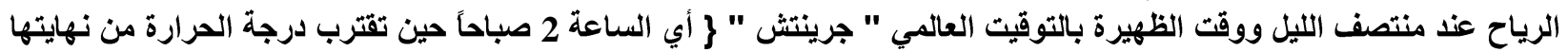
الصغرى ، و الساعة 2 بعد الظهر حين تقترب درجة الحرارة من نهايتها العظى بالتوقيت المحلي ج لتمثيل وتحليل طاقة الرياح ليلاً

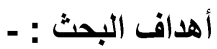

تتبع وتحليل خصائص سرعة الرياح السطحية \} اليومية والساعية \{ في أقاليم مصر الجغرافية.

•

• تحديد أنسب المواقع لإنثاء مزارع الرياح لتوليد الطاقة في ضوء المعطيات الجغرافية .

• تقييم جدوى استغلال طاقة الرياح المتجدة في مصر .

ولتحقيق هذه الأهداف ، يتبع البحث تحليل العناصر التالية : -

• التوزيع الفصلي والثهري والسنوي للسرعة اليومية للرياح .

• محصلة الرياح سرعة واتجاهاً. .

4 ـ قد كانت أول أشارة لتوليد الطاقة من الرياح عند الفرس منذ حوالي 2000 سنة قبل الميلاد في كتاب العرب حيث ذكر الوصف التفصيلي لطواحين

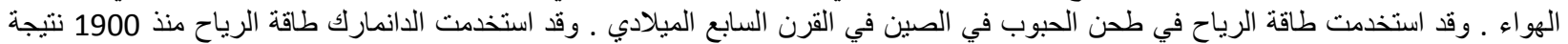

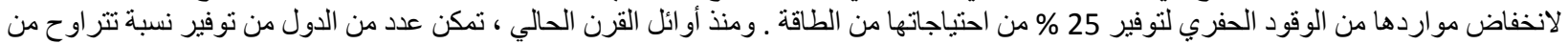

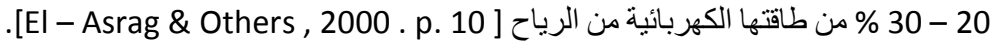

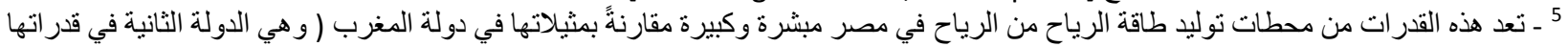

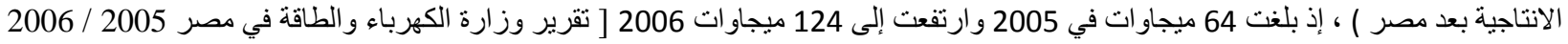

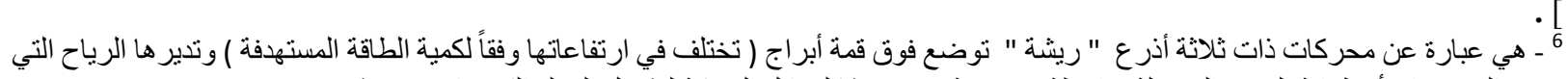

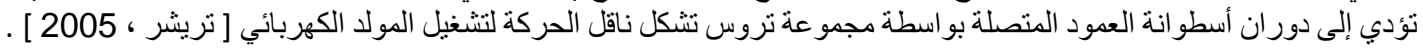

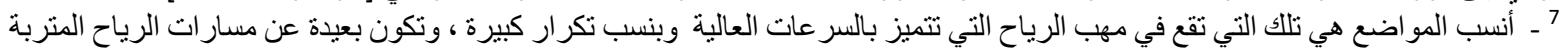
.International Energy Agency (2003) : Renewable Energy Information ,Paris 


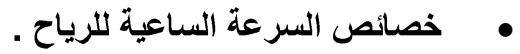

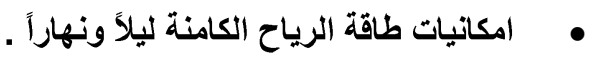 \\ أولاً : التوزيع الفصلى والثهزي والسنوي للسرعة اليومية للرياح: - \\ 1 - المتوسطات الفصلية والشهرية :}

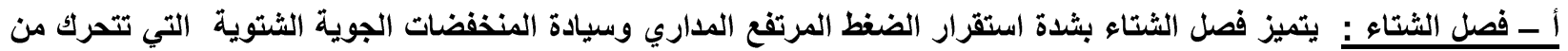

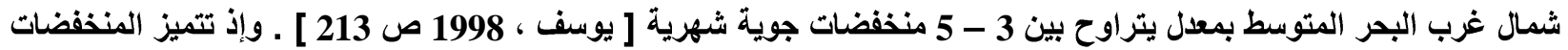

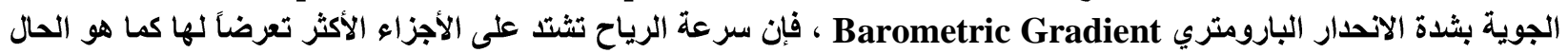

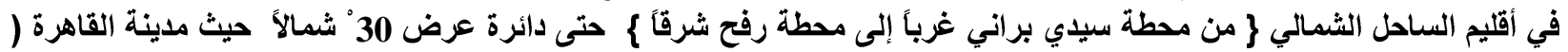

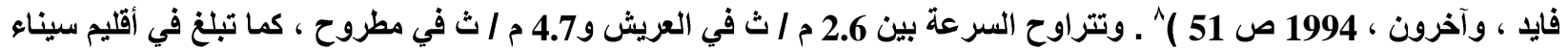

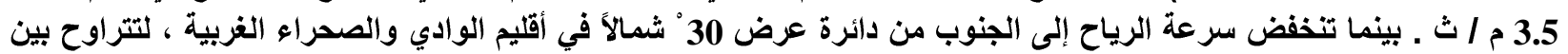

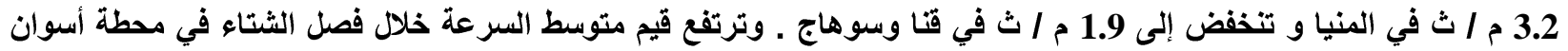

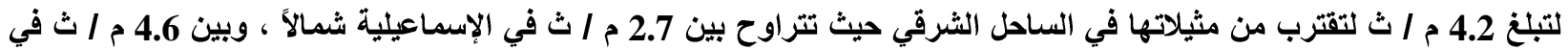

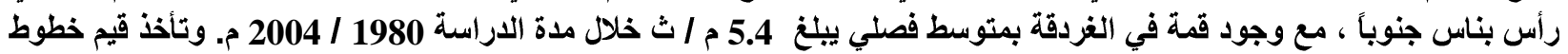

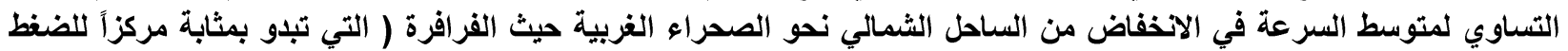

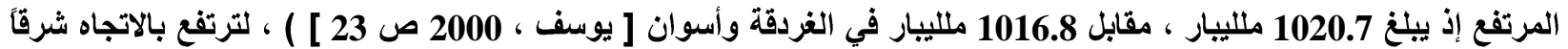

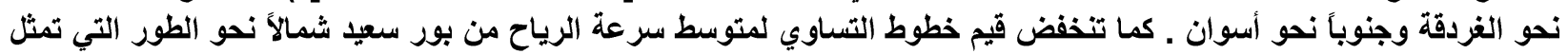

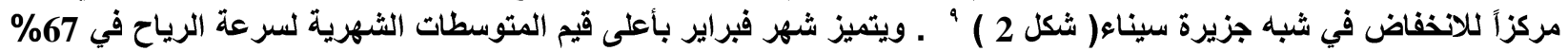

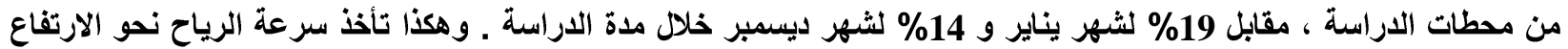

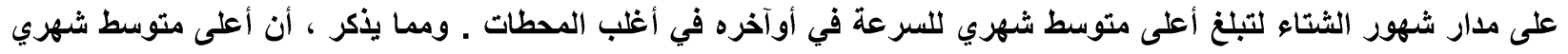

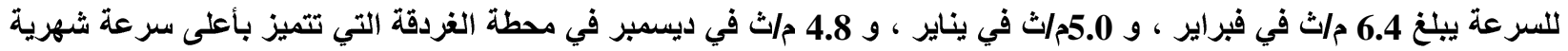
وفصلية للرياح بين المحطات .

ب ـ فصل الربيع: تتغير أحوال الضغط الجوي خلال فصل الربيع مقارنة بالثتاء حيث تنشط المنخفضات الجوية الصحراوية .

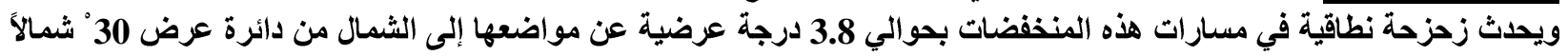

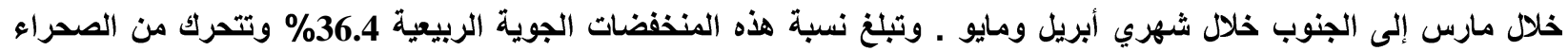
الغربية لتغزو أغلب الأراضي المصرية ( الفقي ، 1999 ـ ص صائ 43 ) ـ ويرتفع متوسط سرعة الرياح خلائ فلال فصل الربيع مقارنة بفصل

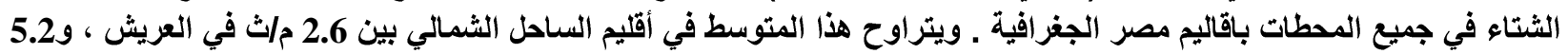

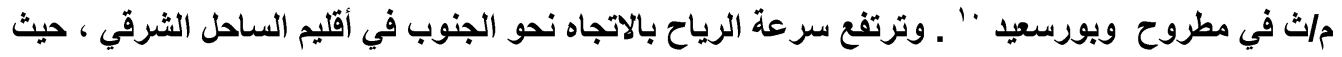

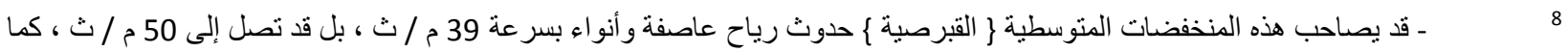

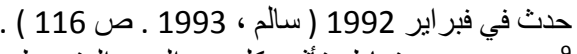

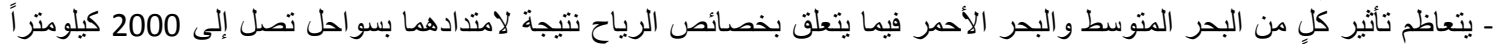

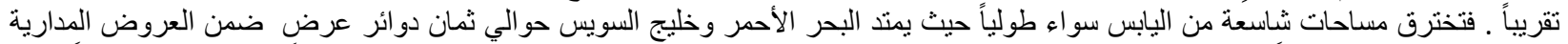

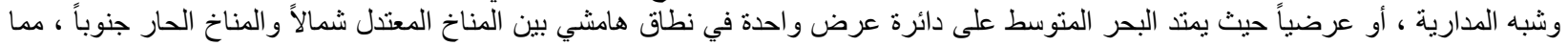

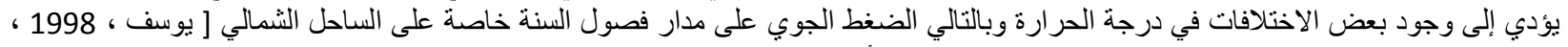

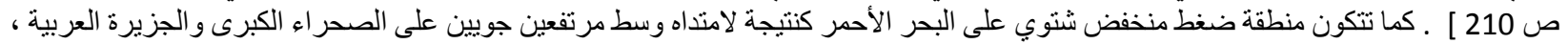

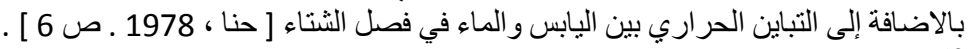

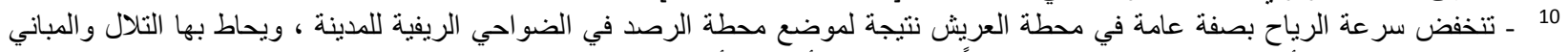

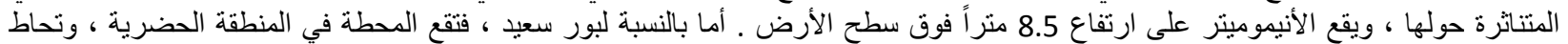

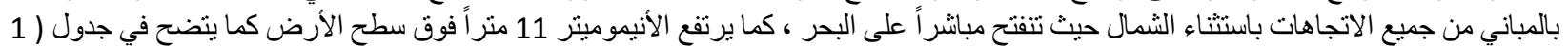
.[ Meteorological Authority ,2000 Egyptian] ( 


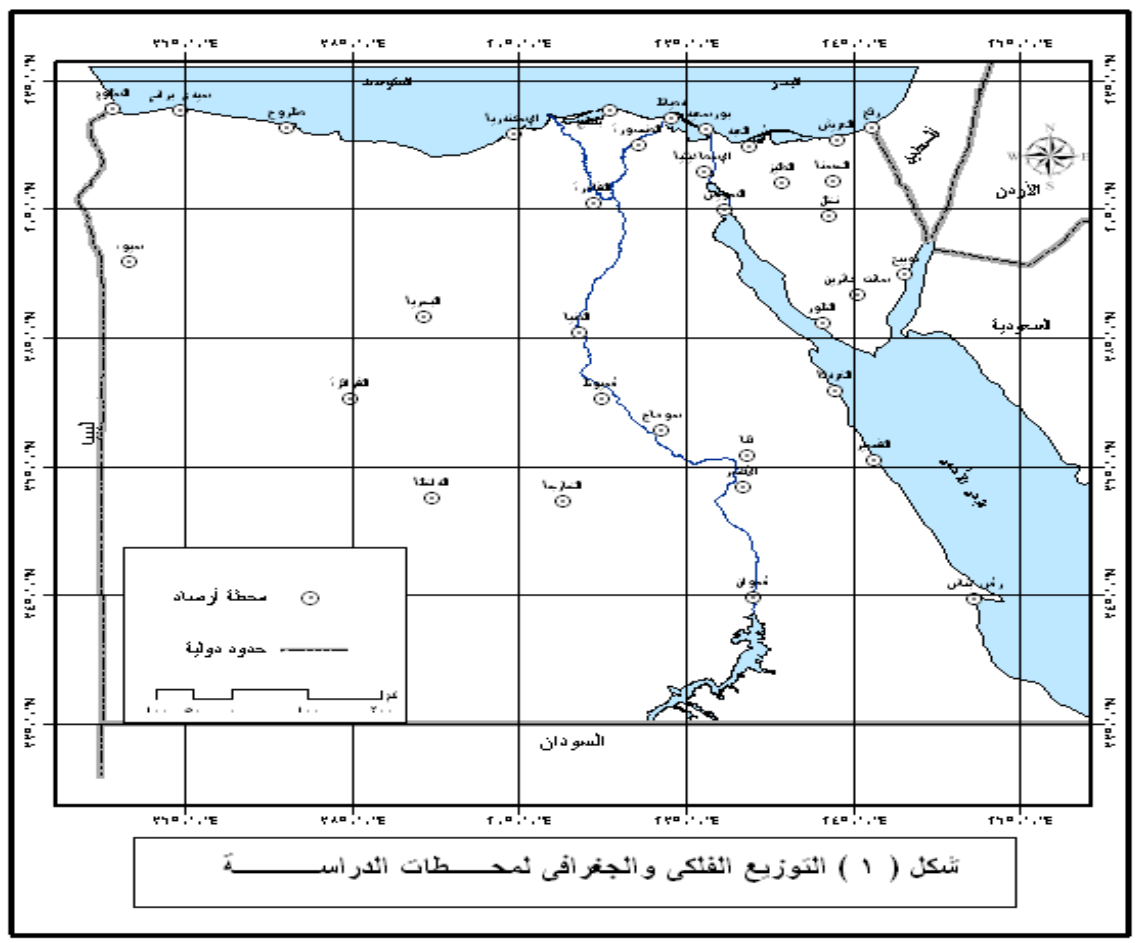

ترتفع من 3.4 م/ث في الإسماعيلية شمالاً إلى 6.0 م/ث في رأس بناس جنوباً " ، كما ترتفع قيم متوسط السرعة ربيعاً في أقليم

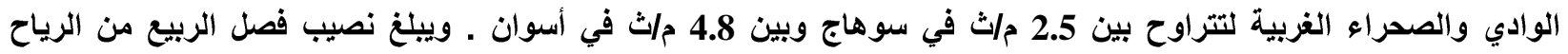

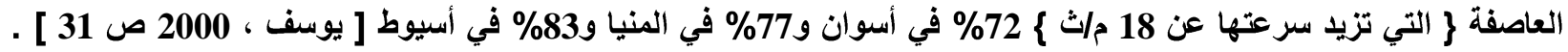

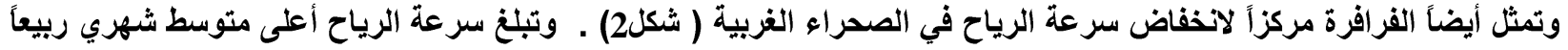

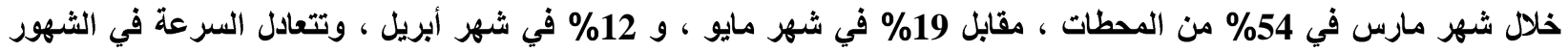

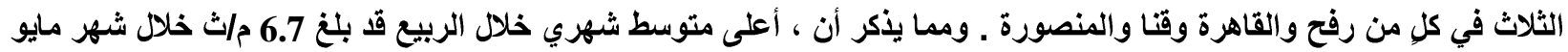

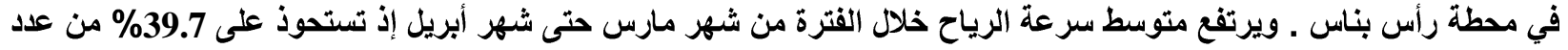

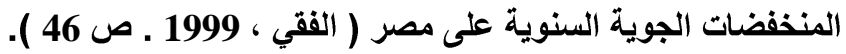

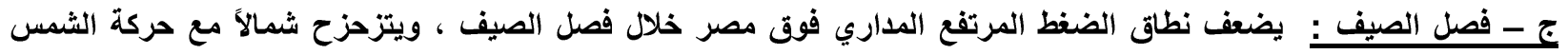

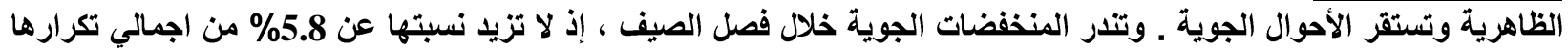

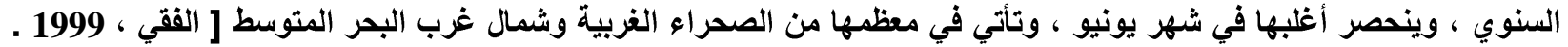

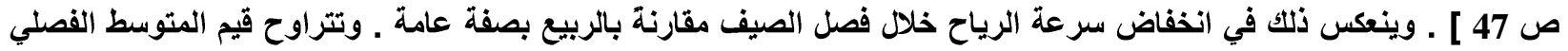

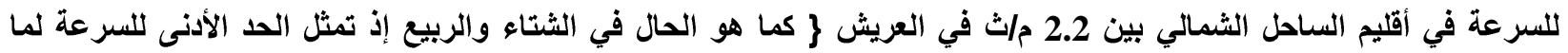

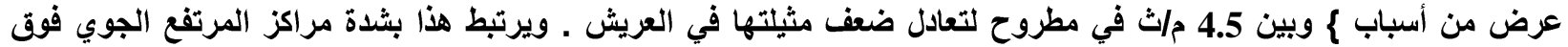

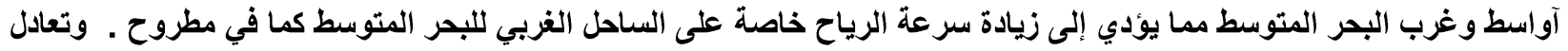

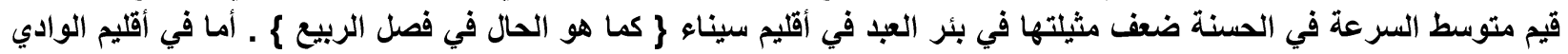

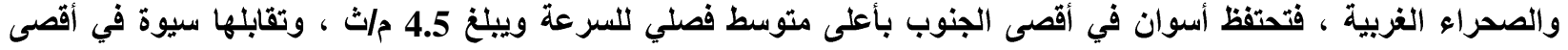

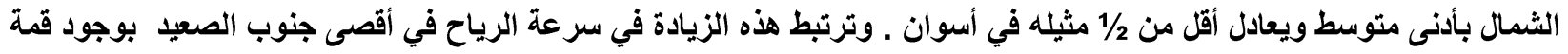

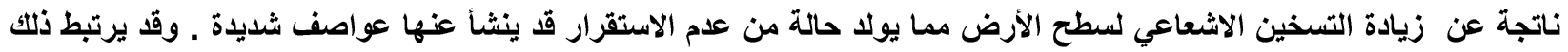

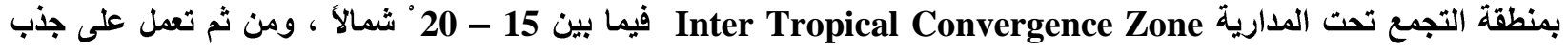

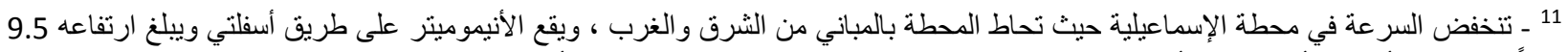

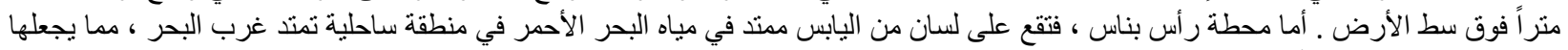

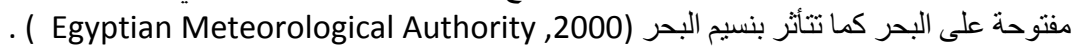




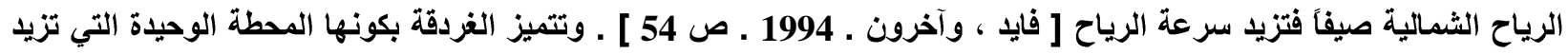

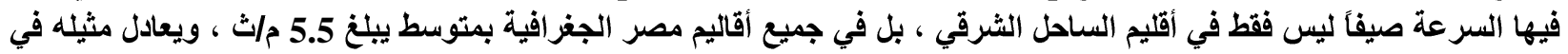

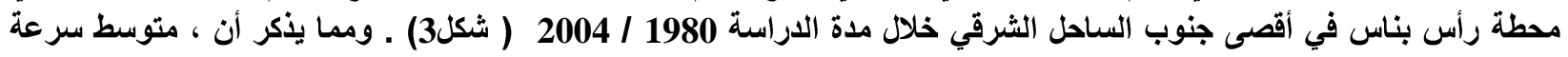

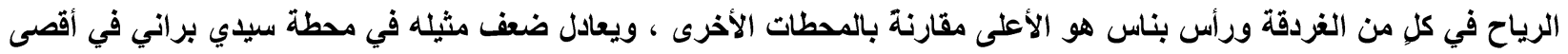

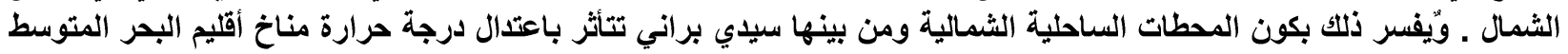

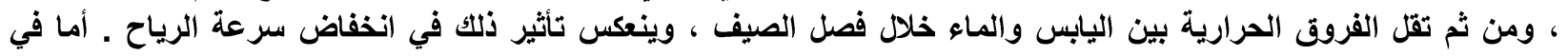

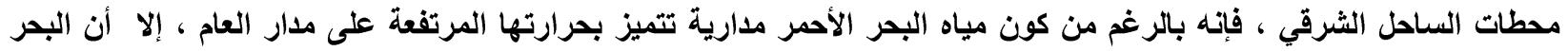

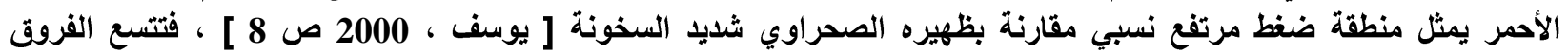

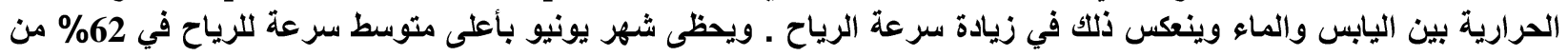

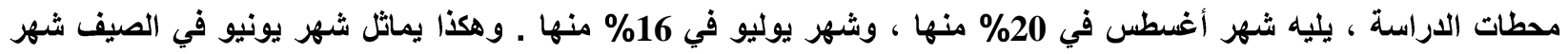

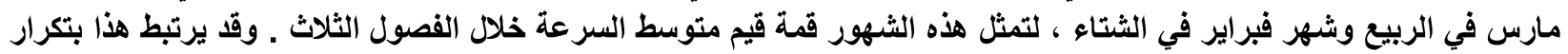

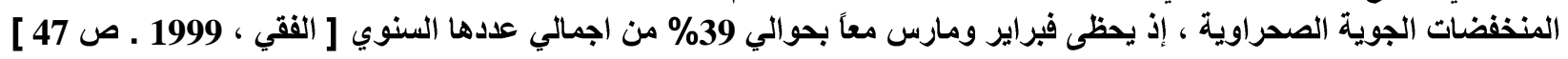

لـ ــصل الخريف : تنخفض سرعة الرياح إلى أدنى مستوياتها خلال فصل الخريف مقارنة بالفصول الأخرى بسبب عدم اكتمال

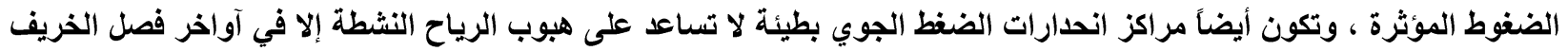

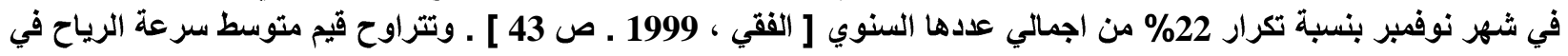

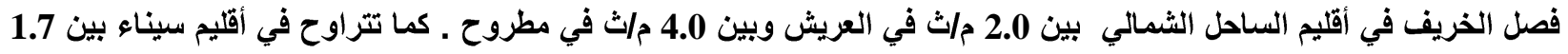

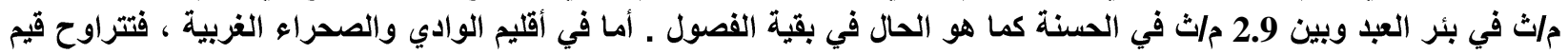

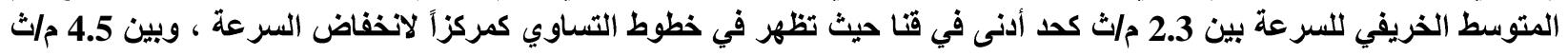

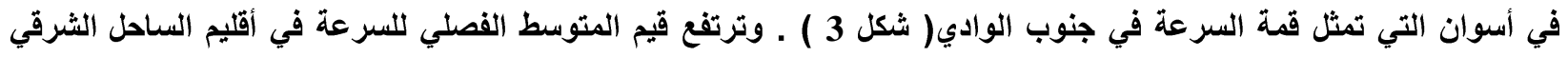

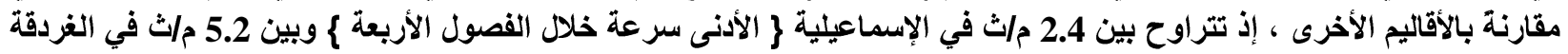

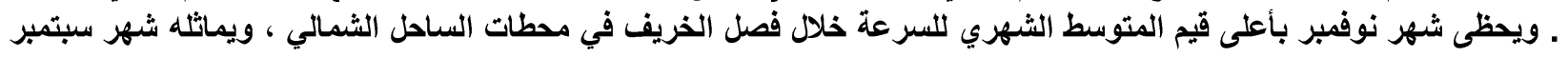

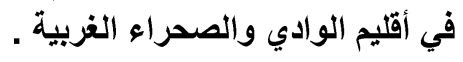

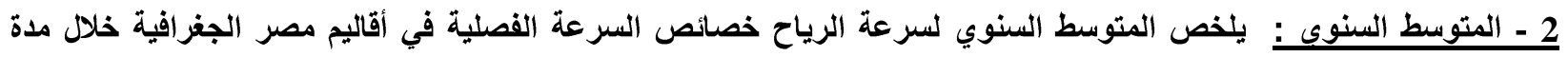

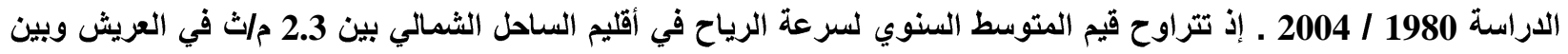

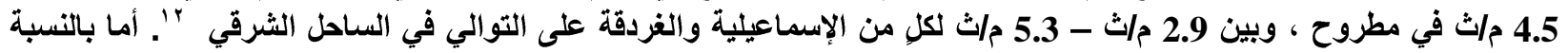

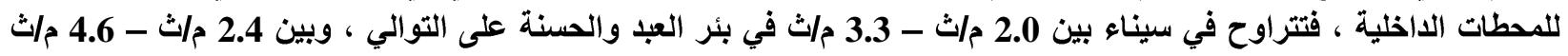

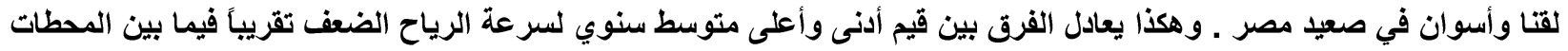

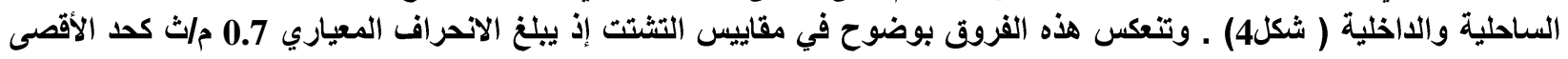

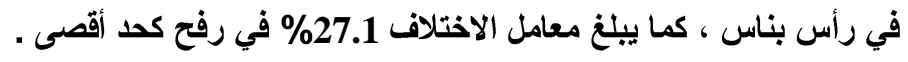

ثانياً: : محصلة الرياح سرعة واتجاهاً: تتحكم سرعة الرياح بصورة مباشرة في امكانيات توليد طاقة الرياح ، مما يدعو إلى ضرورة

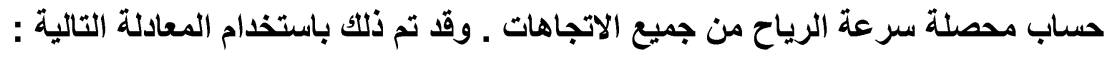

[ V= R/Hr [ Stinger, A.1981.p113

$$
\text { . }
$$

Hr = عداد ساعات الهبوب 744 ساعة للشهور ذات 31 يوماً - 720 ساعة للثهور ذات 30 يوماً - 672 ساعة لشهر فبراير\{.

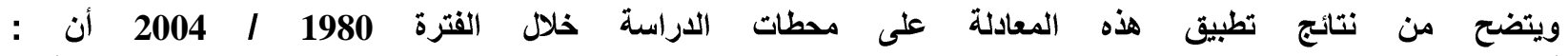
أعلى قيم المتوسطات الثهرية لمحصلة سرعة الرياح Resultant Wind Velocity (V) تحلث خلال فصل الصيف في أقليم

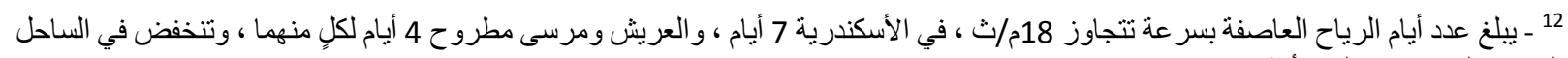

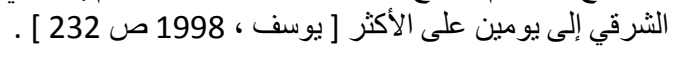


الوادي والصحراء الغربية ، وتتميز محطة أسوان من بينها بأعلى القيم ـ أما بالنسبة لمحطات أقليم الساحل الثرقي ، فتحدث أعلى الثلى

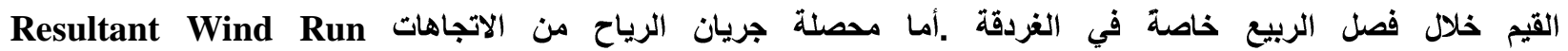

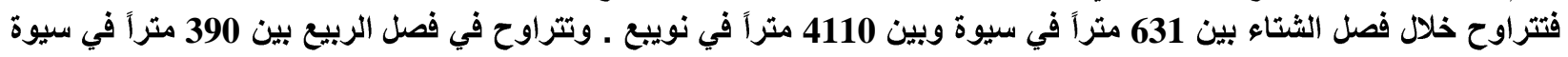

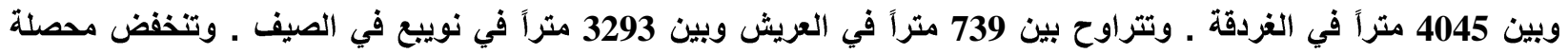

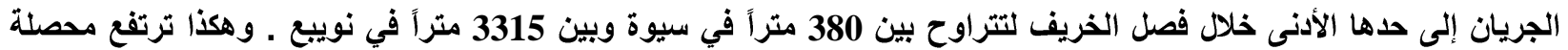

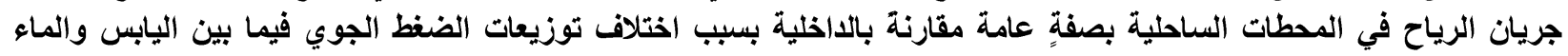

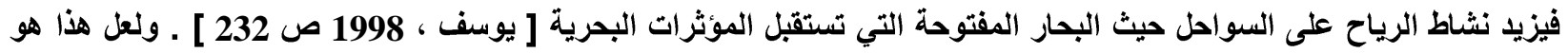

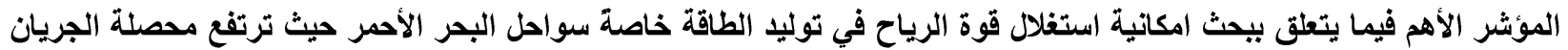

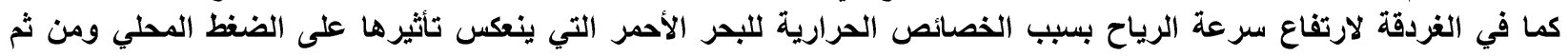

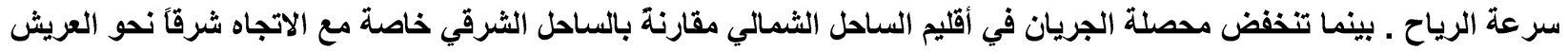

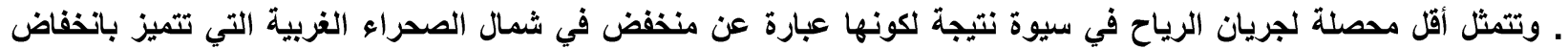

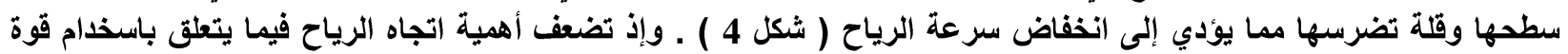

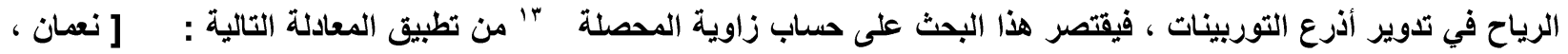

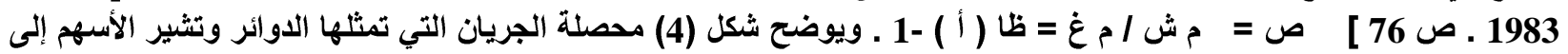
الاتجاه السنوي للرياح السائدة . 


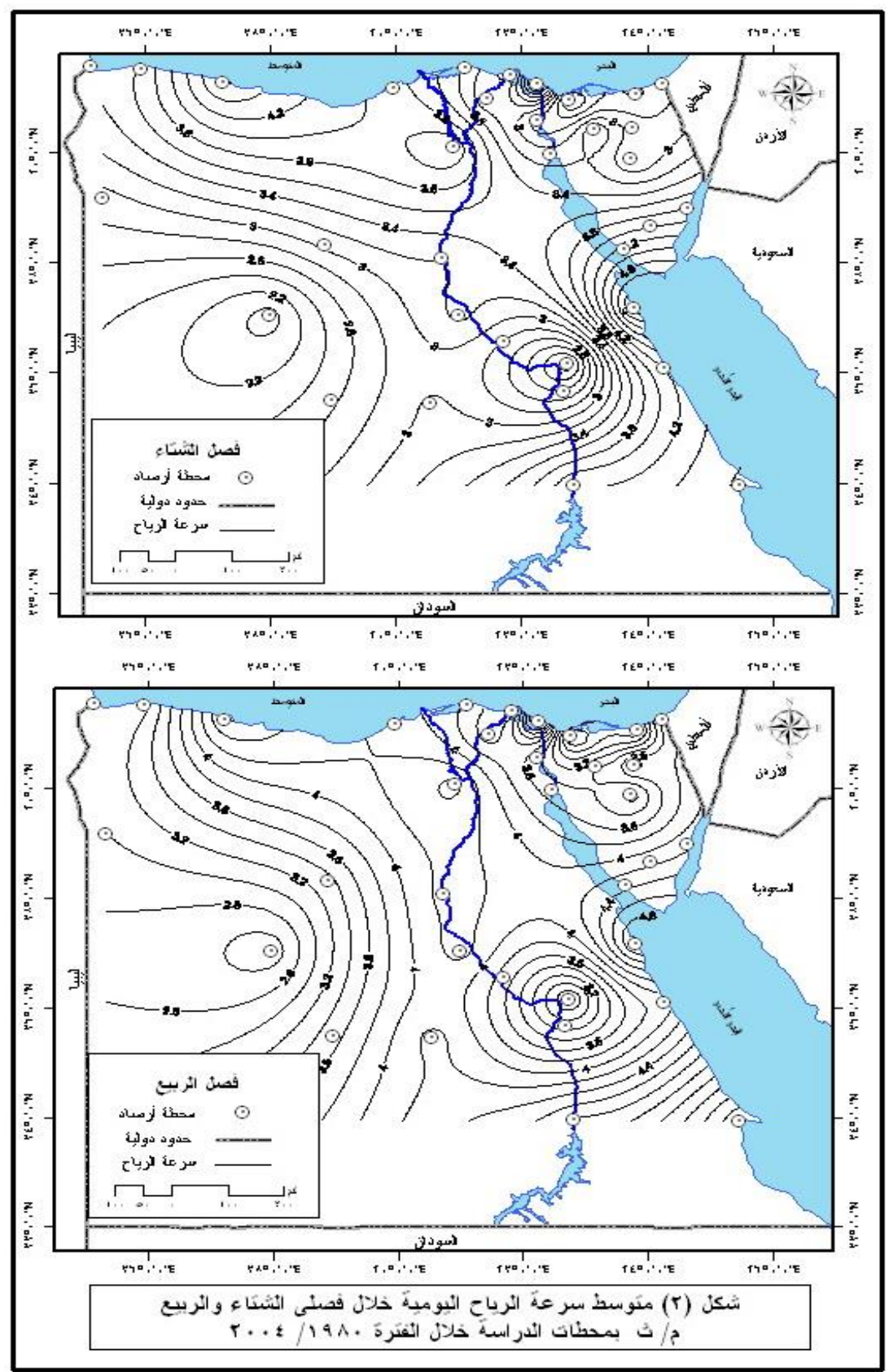




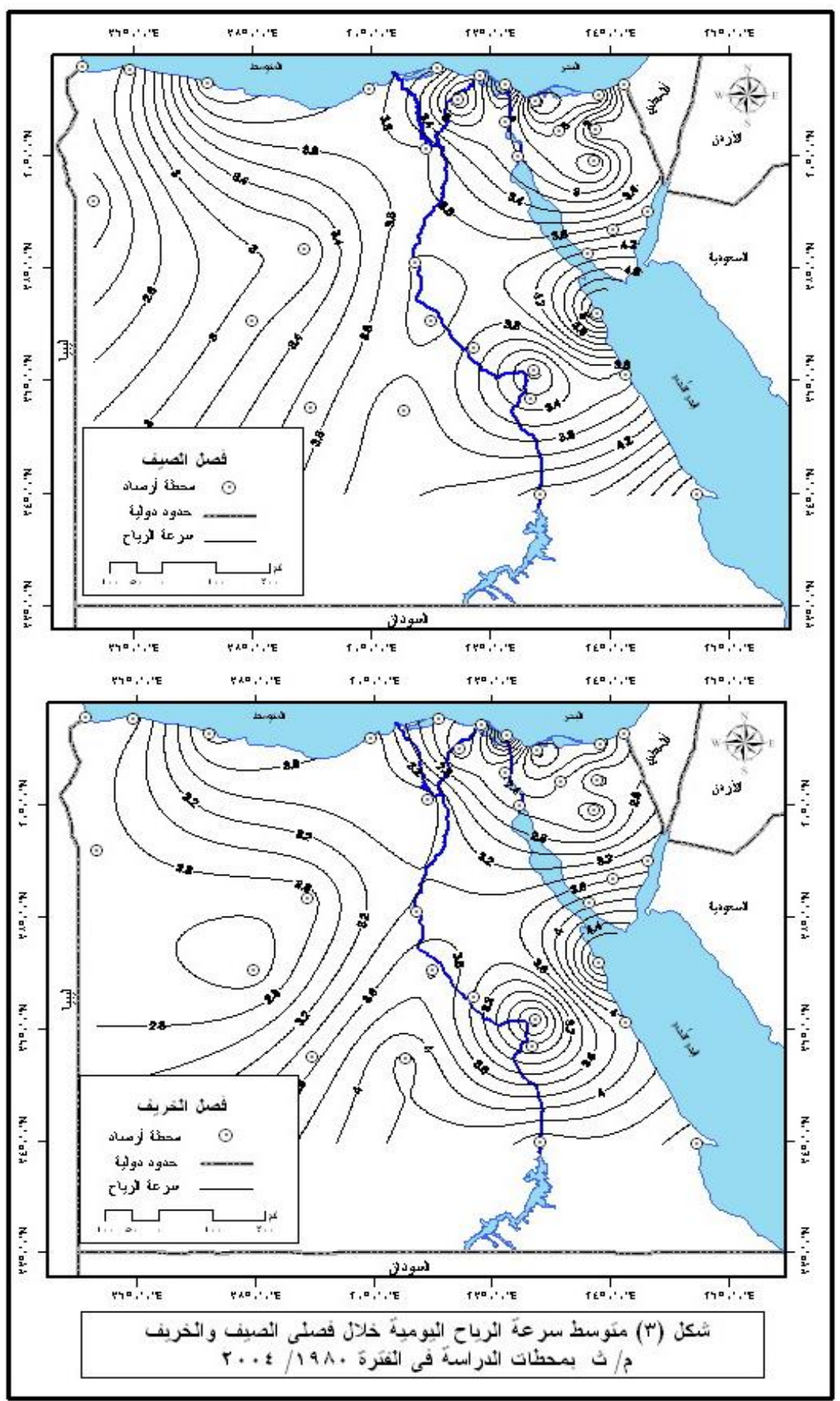




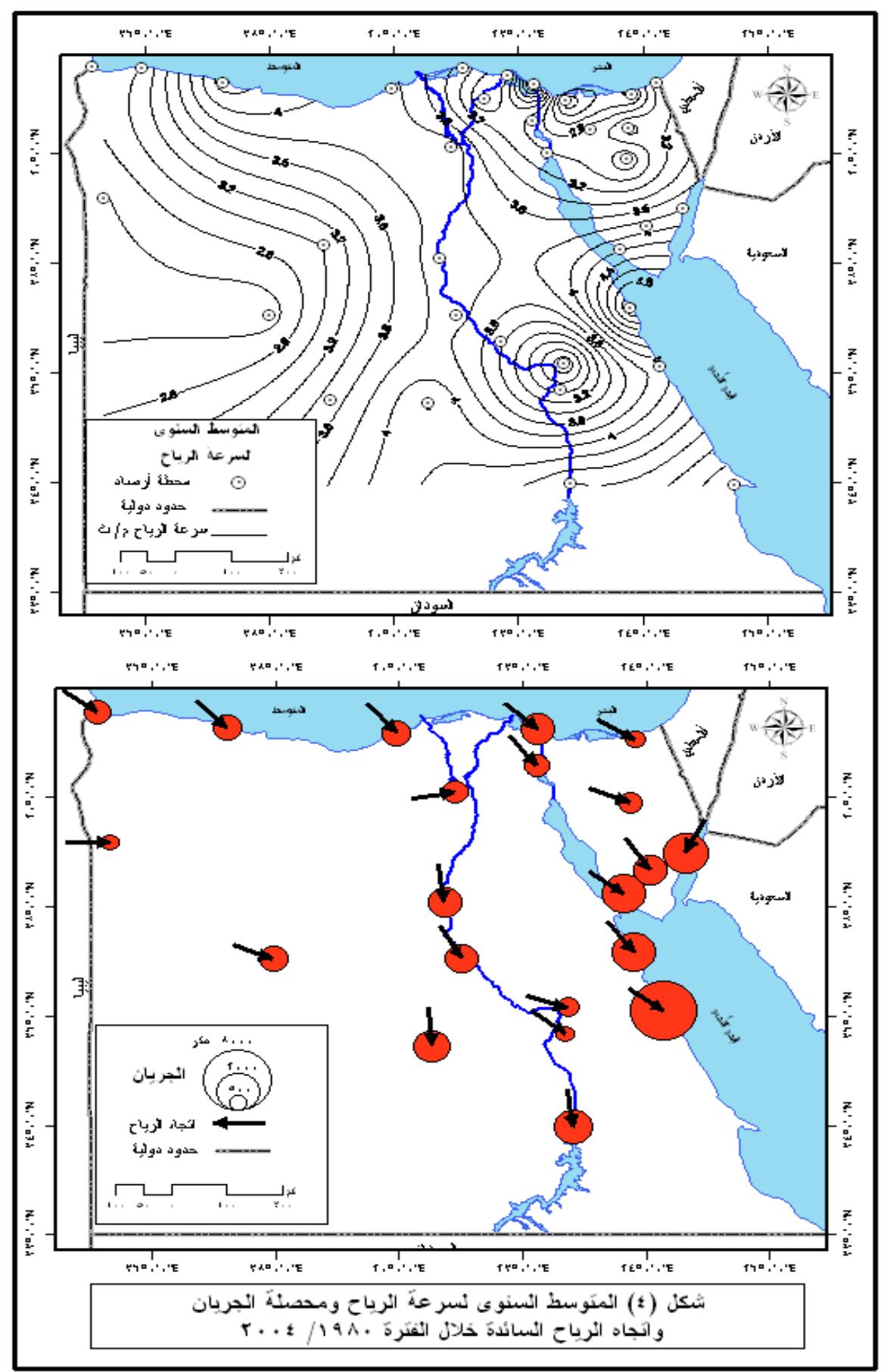

ويتضح سيادة هبوب الرياح من الجهة الثمالية سواء الرياح الثمالية الغربية الأكثر تكراراً في الثتاء والخريف ، ألثاء أوالرياح الثمالية

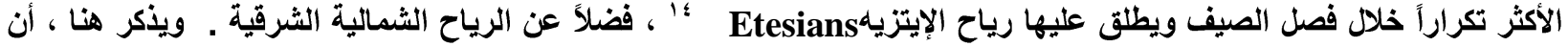

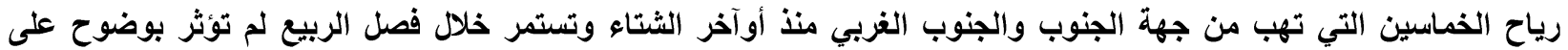

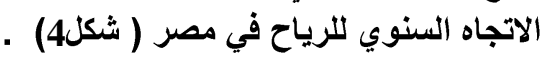

14 ـ تتميز رياح الإيتزيه بخصائص الرياح التجارية فيما بين دائرتي عرض 20-30 ْ شمالاً [ الفقي ، 1999 ص 14 ] . . 


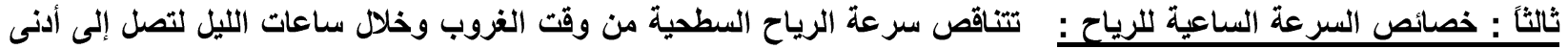

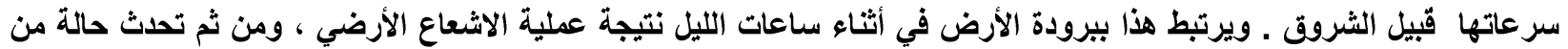

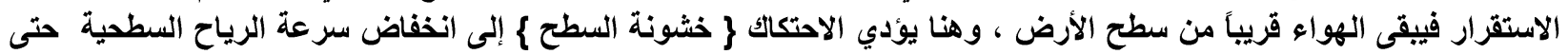

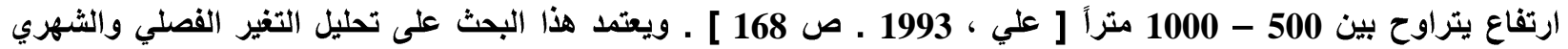
والسنوي في سرعة الرياح عند منتصف الليل وعند الظهيرة بتوقيت جرينتش \} أي الساعة 02 والساعة 14 بالتوقيت المحلي \{ خلال

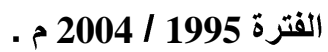

1 - المتوسطات الفصلية والثنهرية عند منتصف الليل :

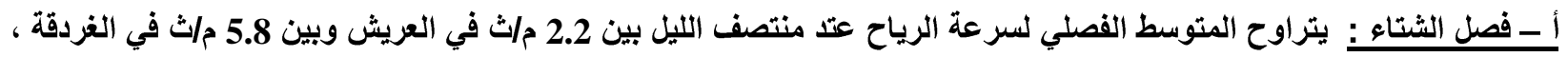

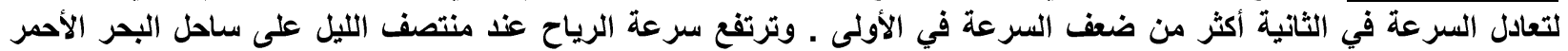

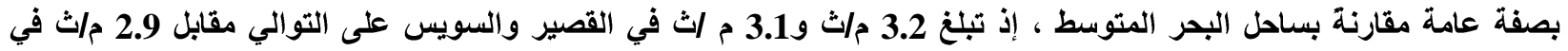

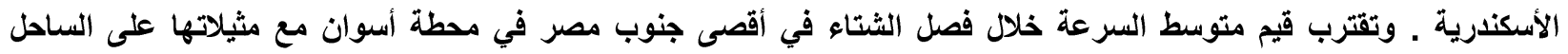

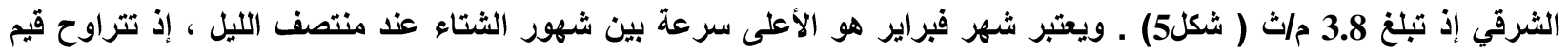

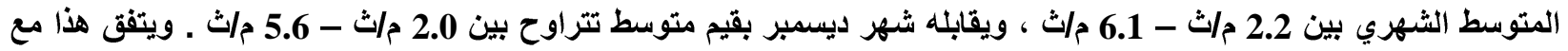

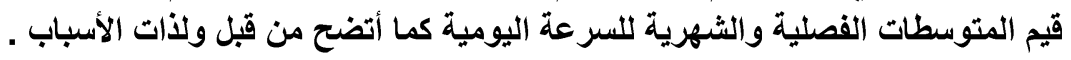

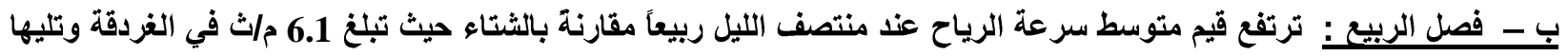

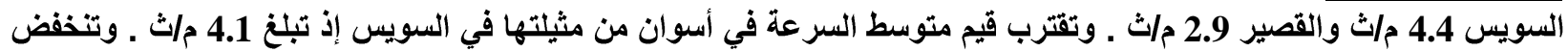

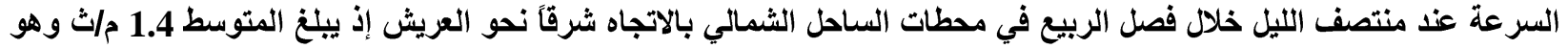

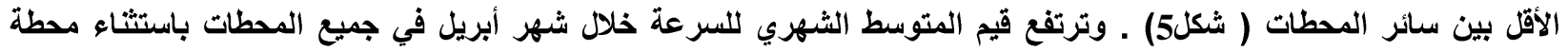

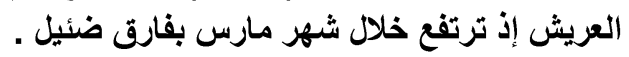

ج ـ فصل الصيف : تحتفظ الغردقة بأعلى متوسط لسرعة الرياح عند منتصف الليل خلال فصل الصيف إذ يبلغ 7.1 ماث لتعاد التعادل

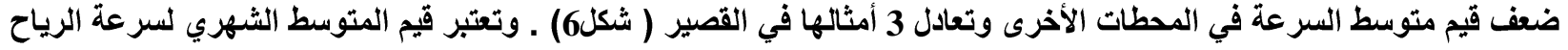

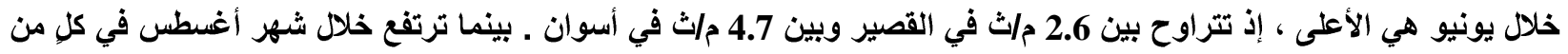
والغزدقة السويس بمتوسط يبلغ 7.3 م/اث للأولى و4.7 مالف ماث في للثانية .

لـ ـ فصل الخريف : ينخفض متوسط سرعة الرياح عند منتصف الليل في فصل الخريف مقارنة بفصل الصيف في جميع المحطات

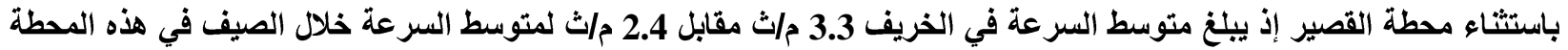

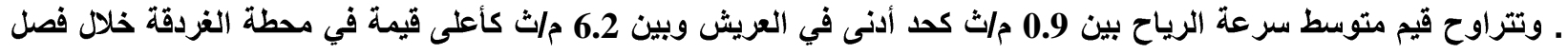

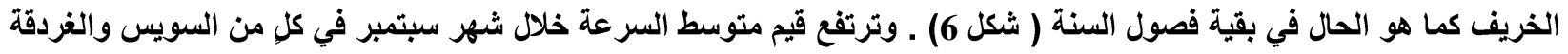
والأسكندرية لتتراوح بين 3.9 م/ث - 6.9 ماث ـ بينما ترتفع خلال شهر نوفمبر في كل من العريش والقصير وأسوان بمتوسط يتراوح بين 1.3 م/ث - 3.8 م/ث عند منتصف اللئ ماث 


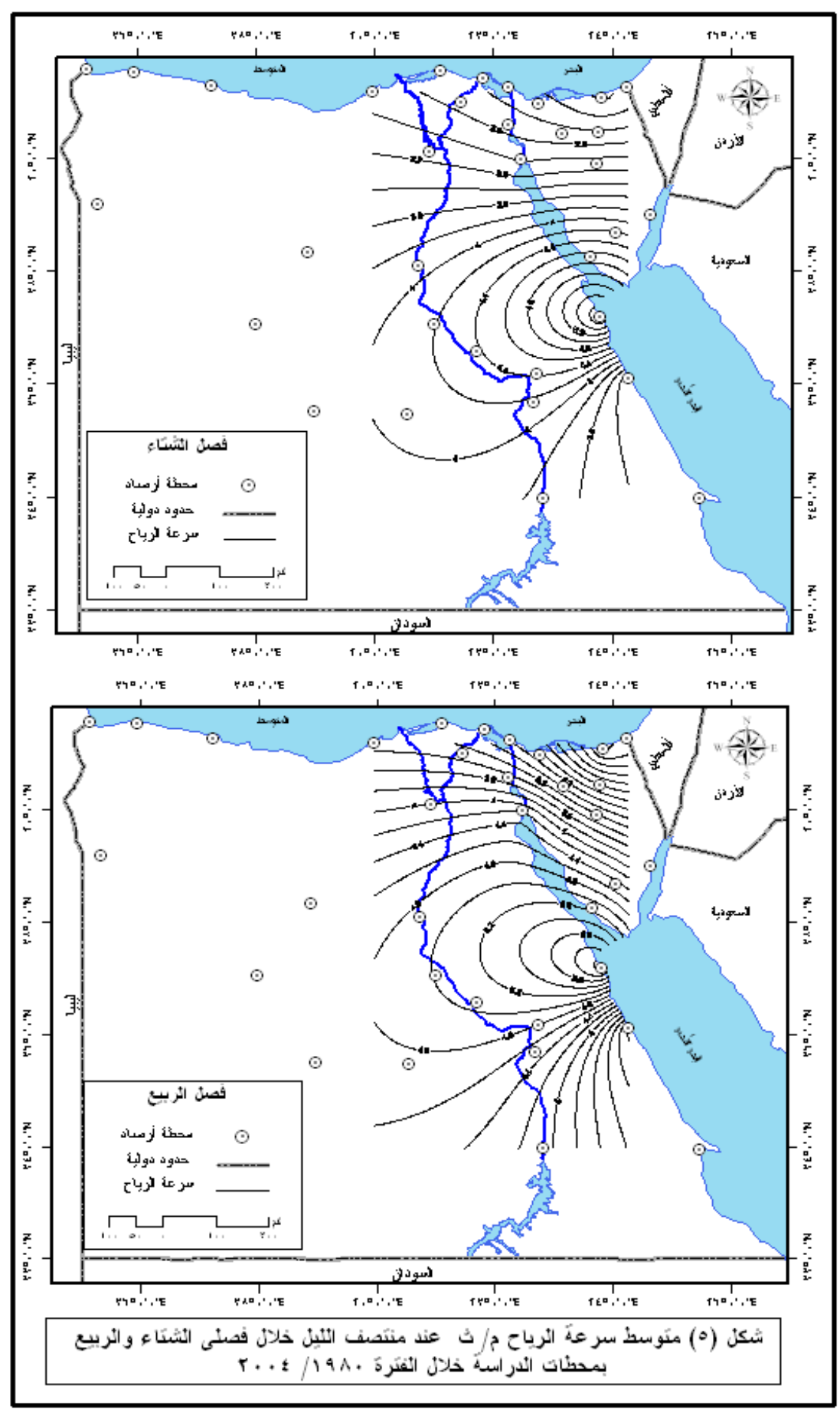




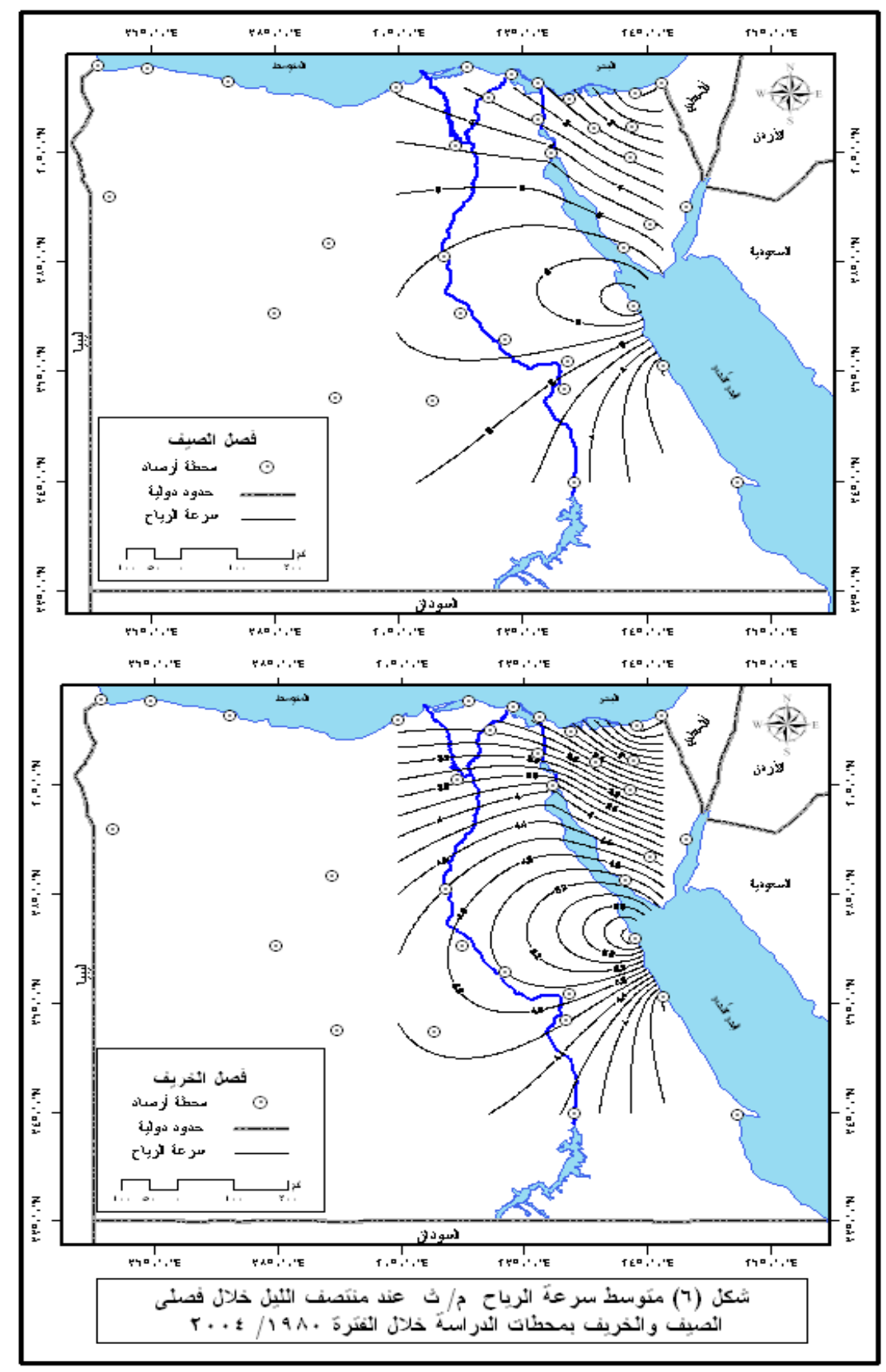

ملاحظة : المحطات التي لا تشملها خطوط التساوي في شكل 5 وشكل 6 لا تتوفر لها بيانات سرعة الرياح عند منتصف الليل . 2 ـ المتوسطات الفصلية والثهرية عند الظهيرة :

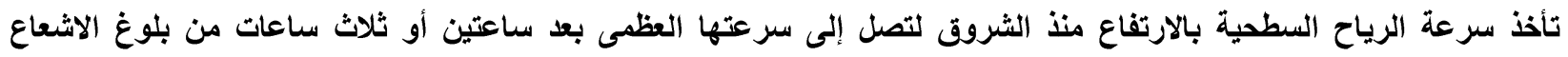

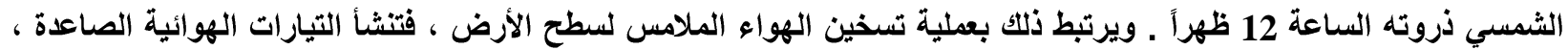

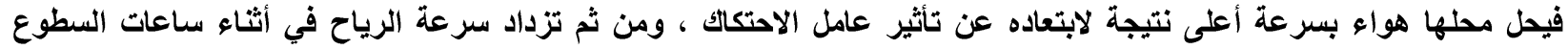
مقارنة بساعات الليل . 
أ ـ فصل الثتاء : يرتفع متوسط سرعة الرياح عند الظهيرة مقارنة بمنتصف الليل ـ وتمثل محطة سيدي براني أعلى قيم لمتوسط

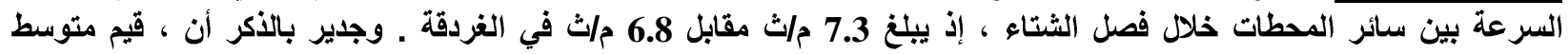

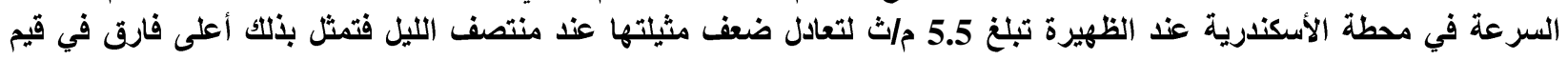

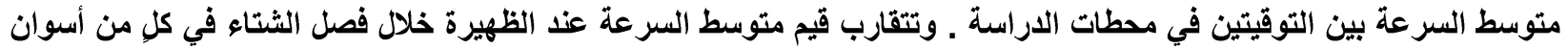

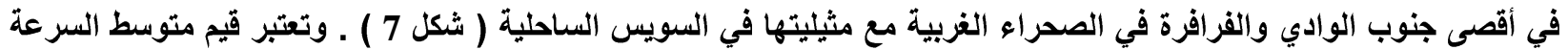

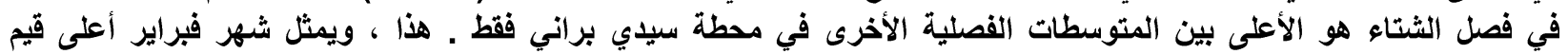

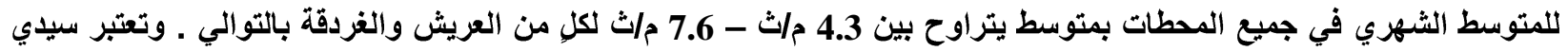
براني هي الاستثناء الوحيد في ذلك ، إذ ترتفع في شهر يناير لتعادل أكثر من ضعف مثيلتها في شهر فبراير .

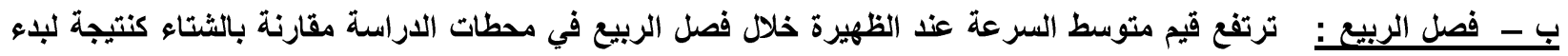

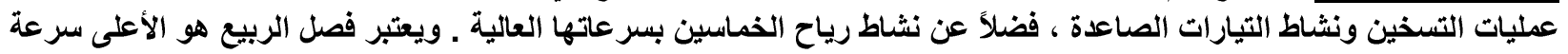

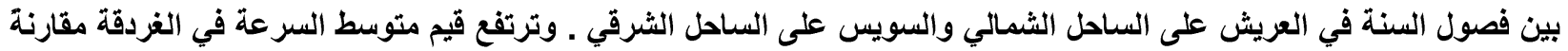

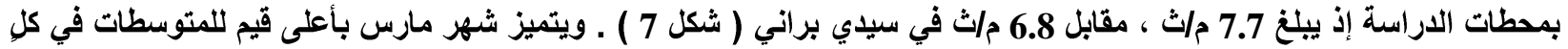

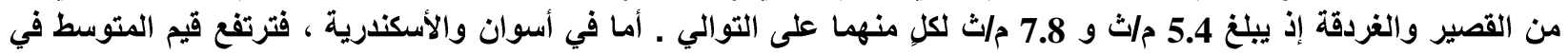

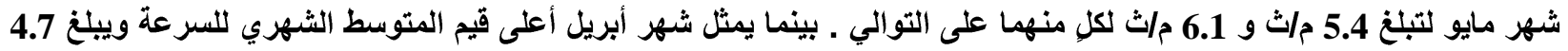
م/ث في العريش ويبلغ 5.0 م/ث في في الفرافرة .

ج ـ فصل الصيف: : ترتفع قيم متوسط السرعة خلال فصل الصيف مقارنة بالربيع عند الظهيرة في محطات أسوان والفرافرة

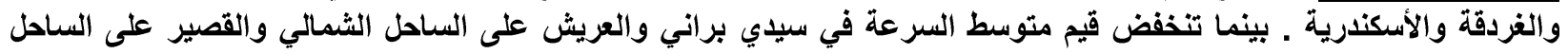

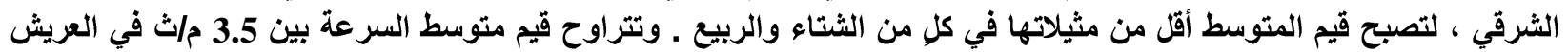

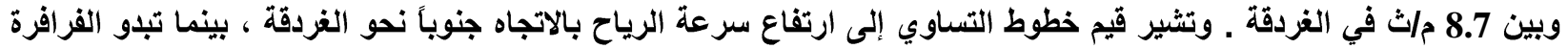

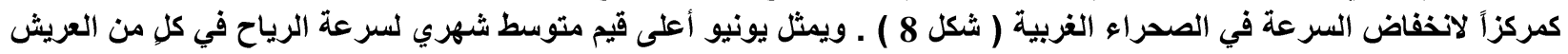

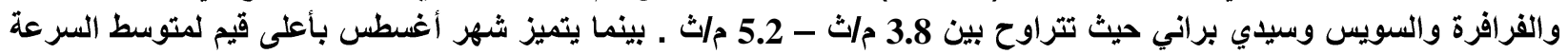
على الساحل الثرقي في كل من القصير والغردقة ، ويمثل شهر يوليو العيد أعلى متوسط شهري عند الظهيرة خلال فصل الصيف في

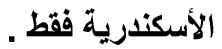

لـ ـ فصل الخريف : يمثل فصل الخريف أعلى قيم المتوسطات الفصلية لسرعة الرياح عند الظهيرة في محطة القصير فقط ، حيث يبلغ

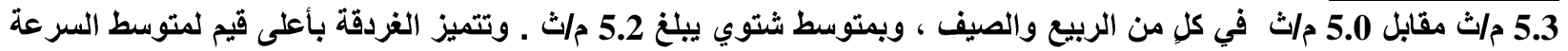

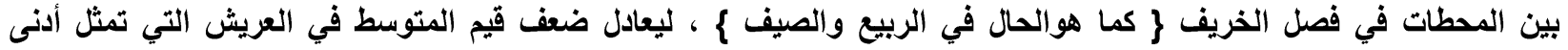

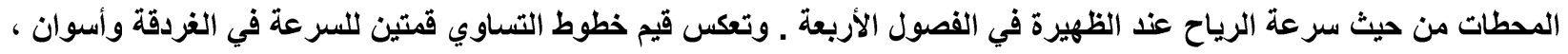

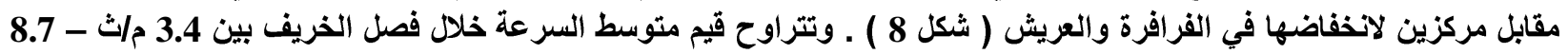

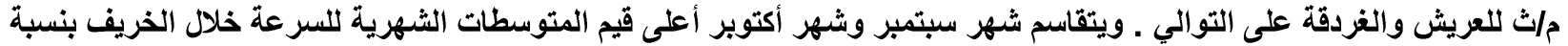
تبلغ 65.5\% و 34.5\% لكل منهما على التوالي من محطات الدراسة . 


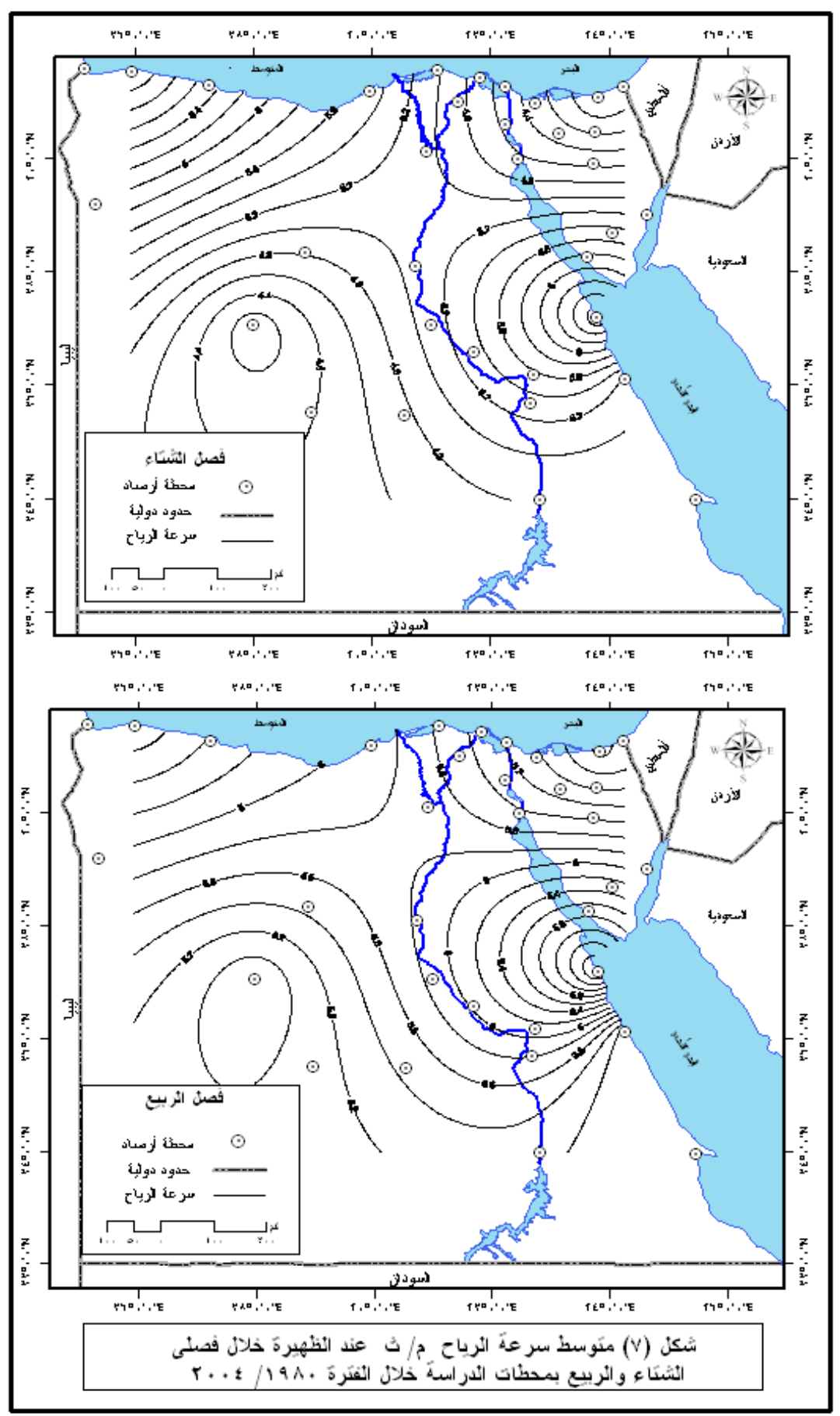




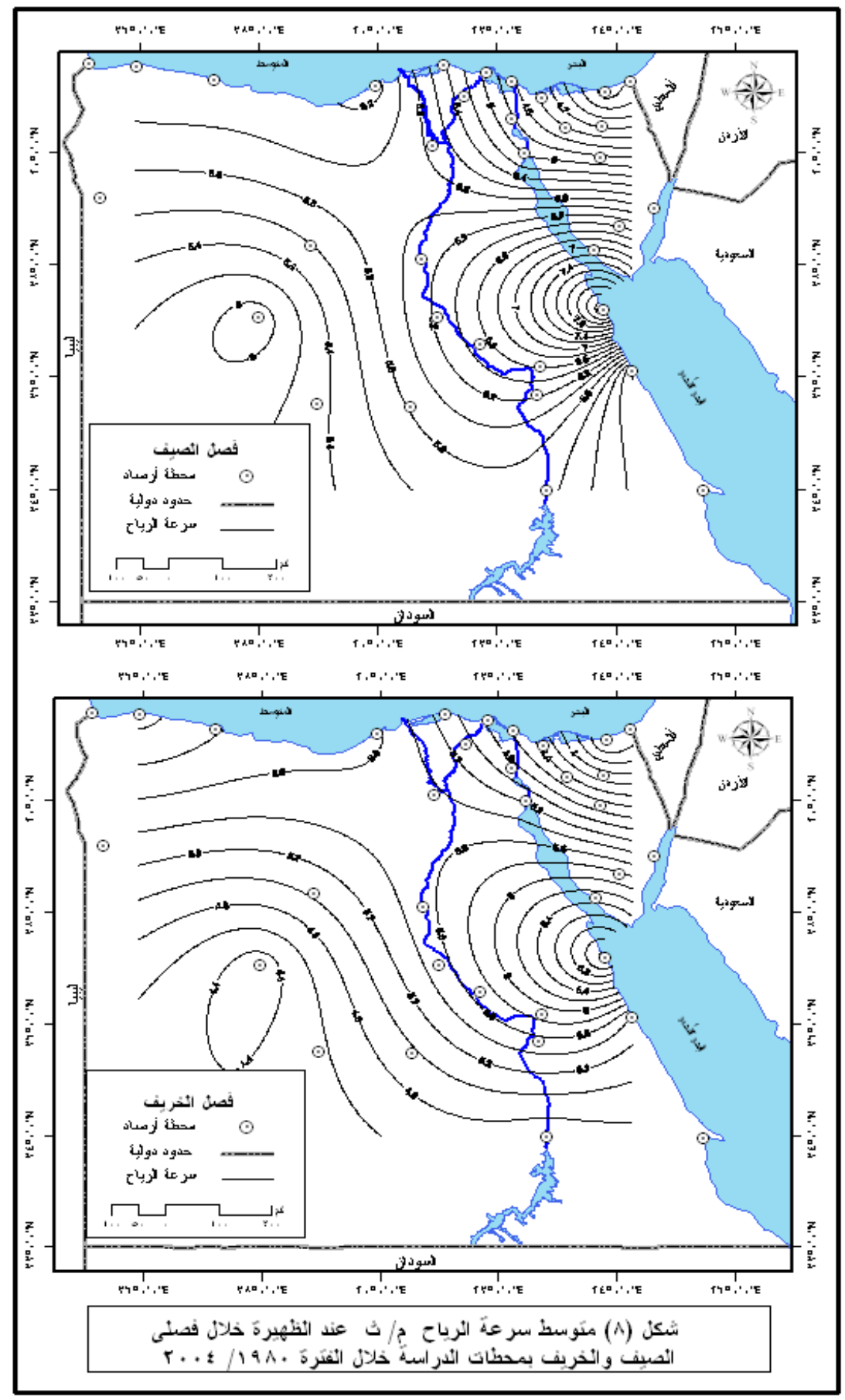




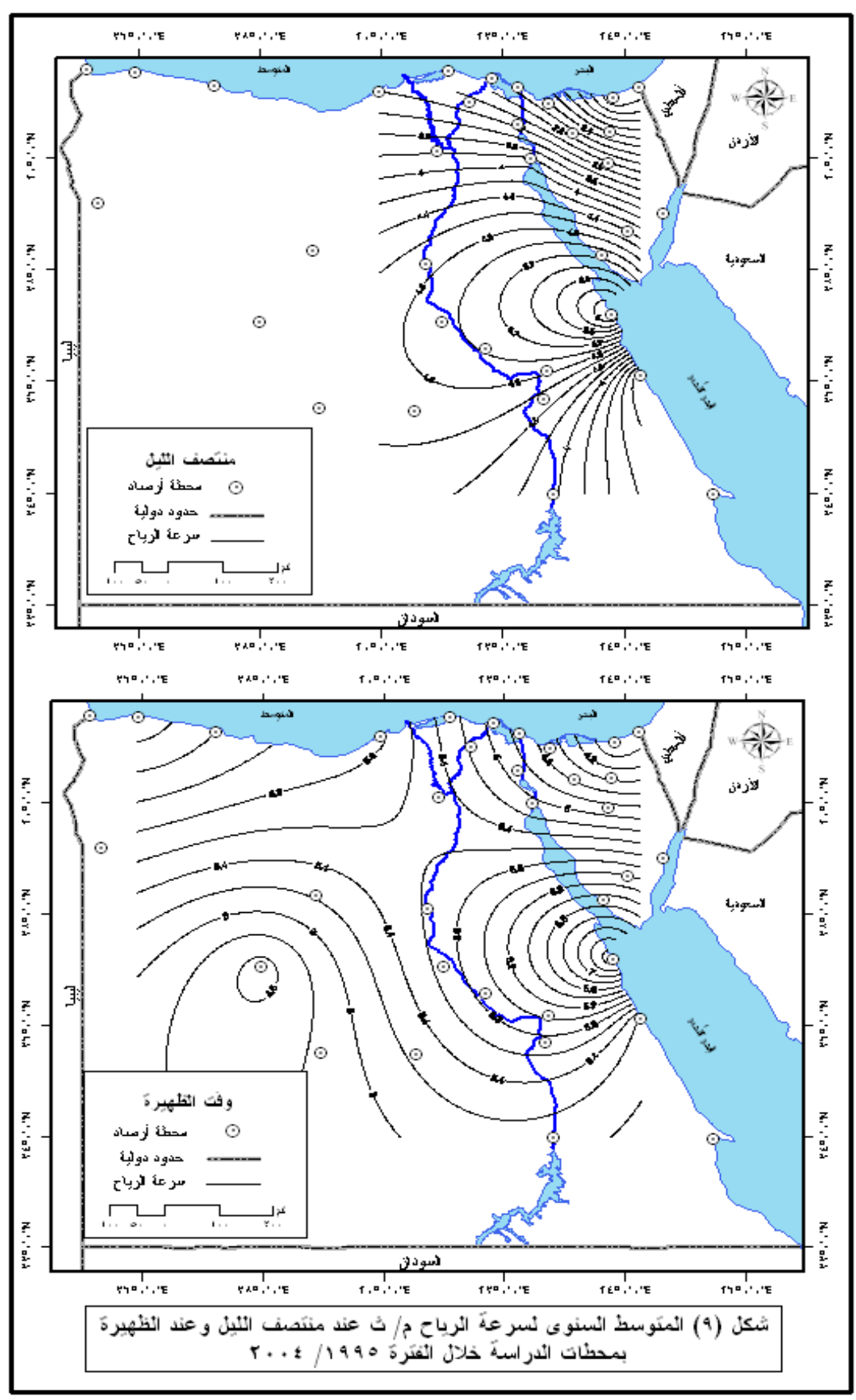

ملاحظة : المحطات التي لا تثملها خطوط التساوي في شكل 9 لا تتوفر لها بيانات سرعة الرياح عند منتصف الليل . المتوسط السنوى لسرعة الرياح ليلاً ونهاراً:

يلخص المتوسط السنوي للرعة الرياح عند منتصف الليل الخصائص الفصلية للسرعة خلال مدة الدراسة 1995 - 2004 ـ ـ وتظهر

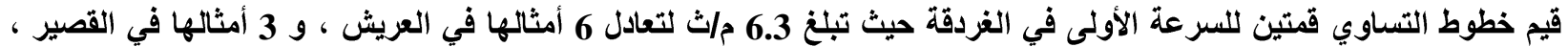

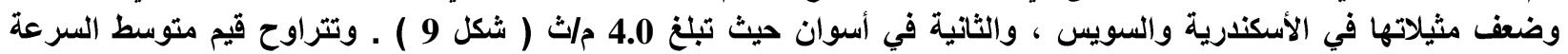
السنوي عند الظهيرة بين 3.8 م/ث في العريش وبين 7.6 م/ث في الغردقة التي تمثل قمة واضحة أيضاً للسرعة نهاراً. وتتثارب قيم فئ 


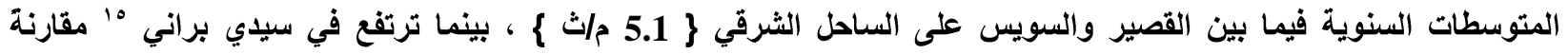

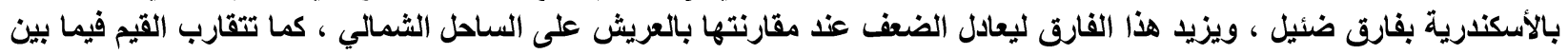

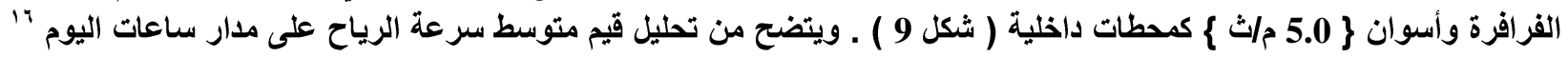

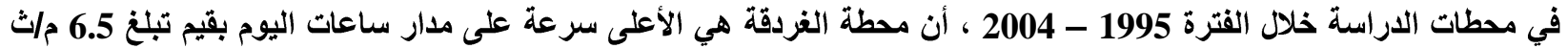

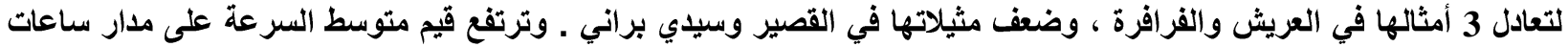

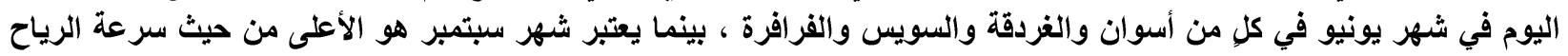

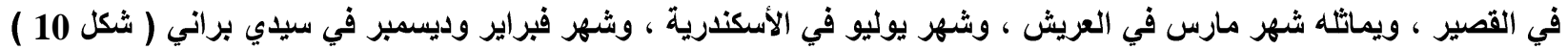

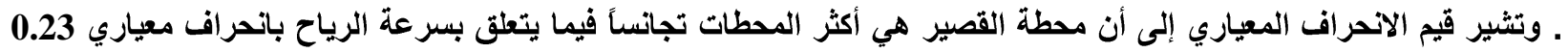

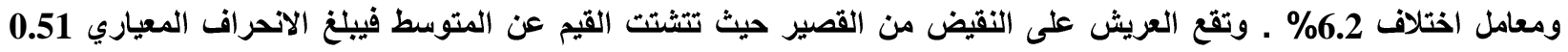

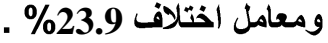

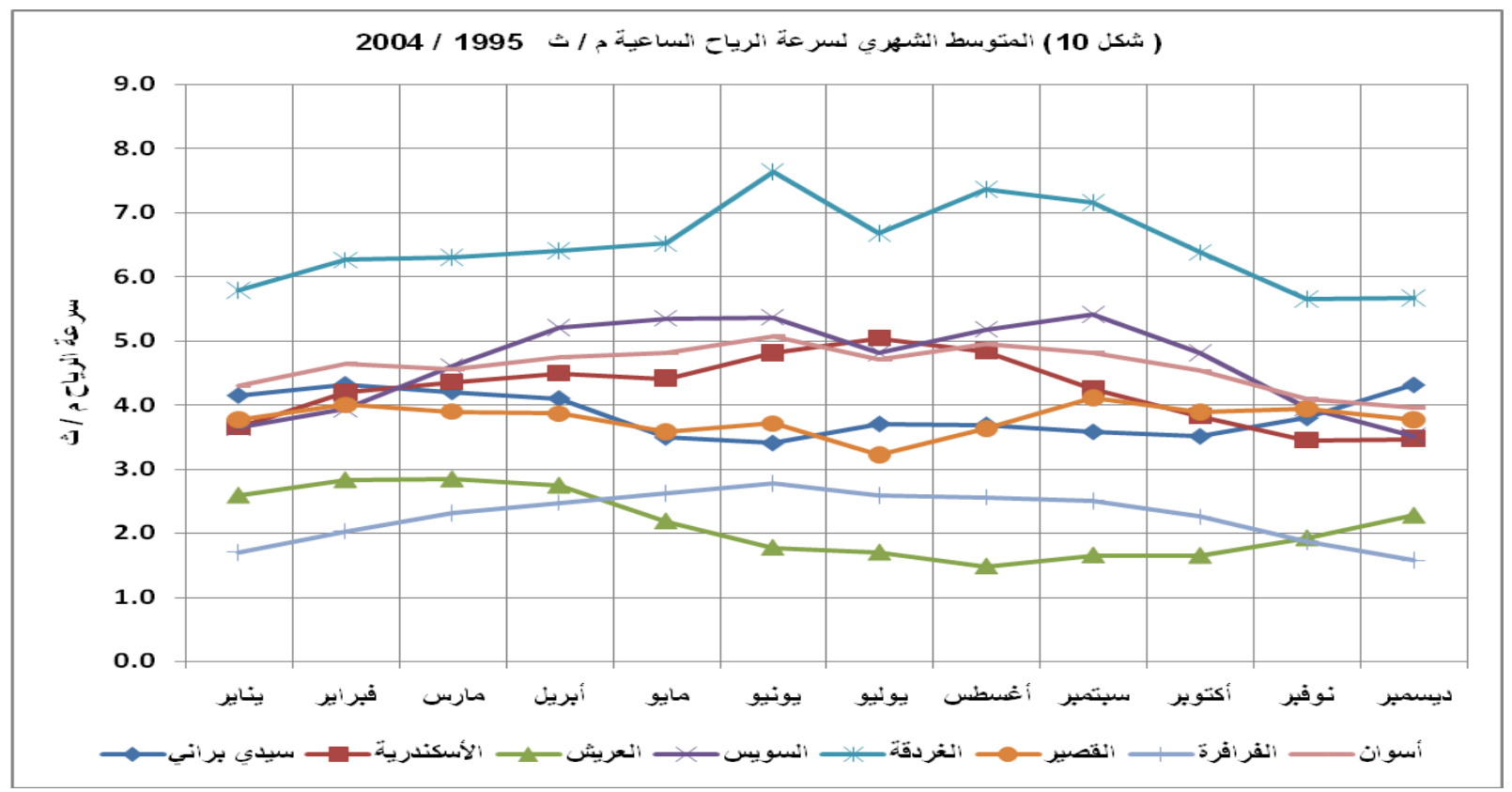

رابعاً : امكانيات طاقة الرياح الكامنة ليلاً ونهاراً :

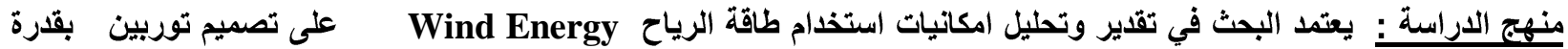

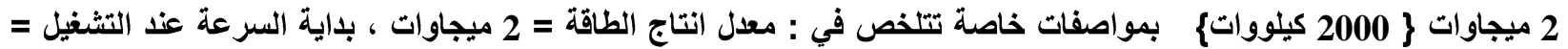

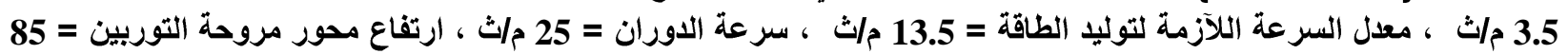

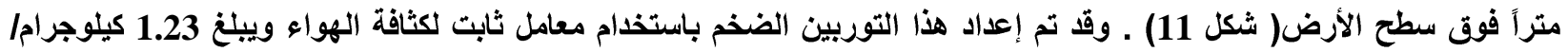

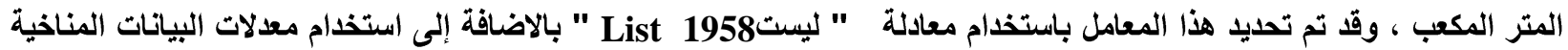

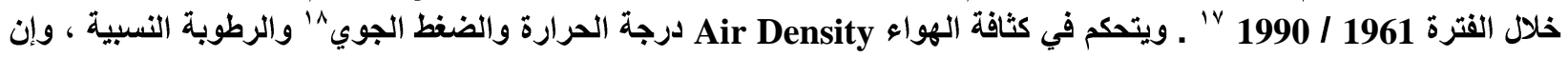

16 16

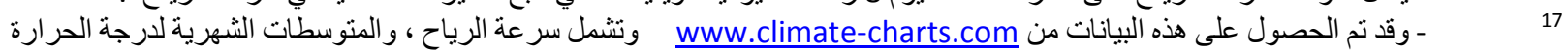

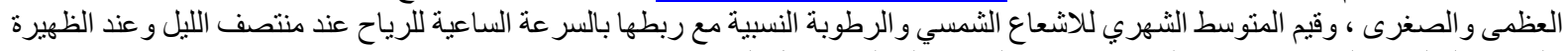

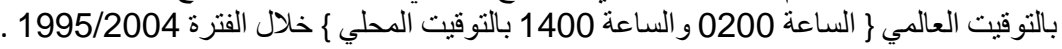

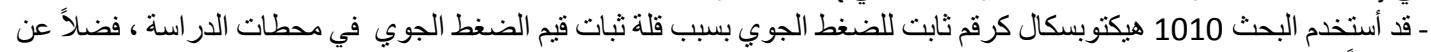

ضعف تأثيره مقارنةً بدرجة الحرارة والبحث الرطوبة النسبية. 


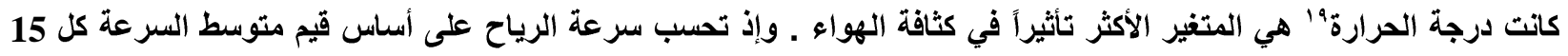

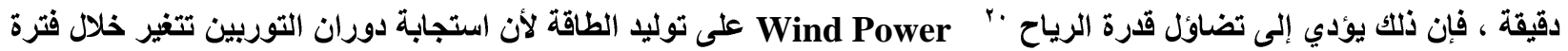

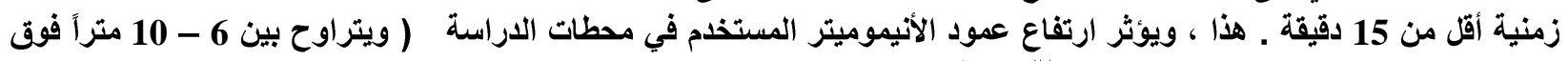

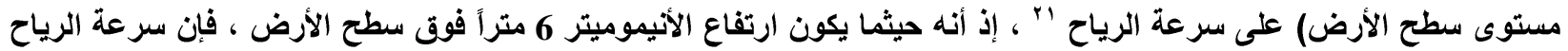

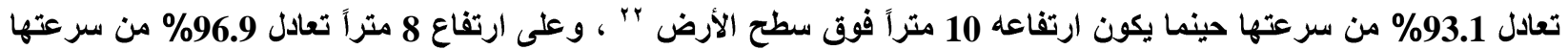

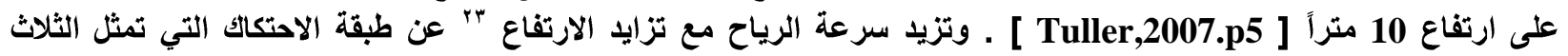

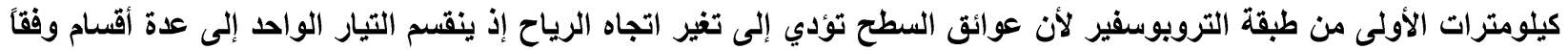

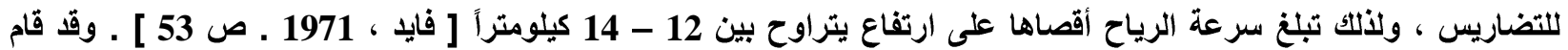

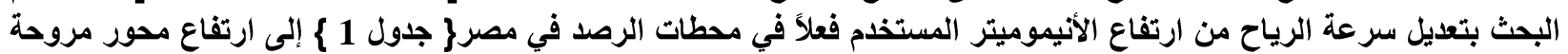

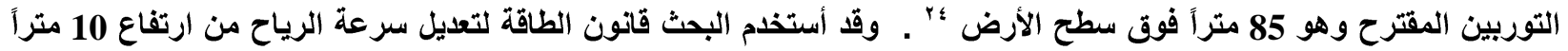

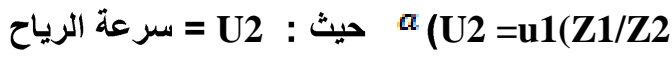
$=\mathbf{Z 2}$

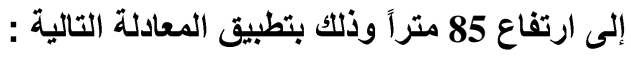

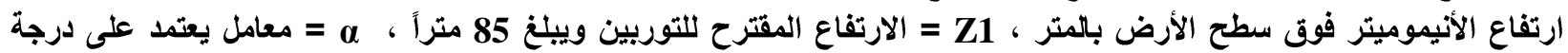

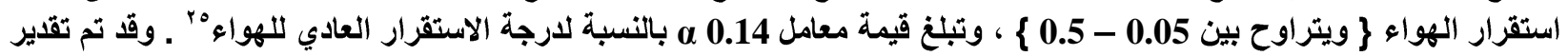

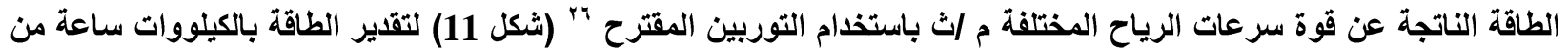

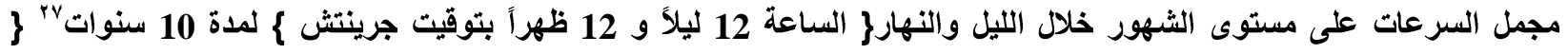

- ولذا اعتمد البحث على قيم المتوسط الثهري لدرجة الحر ارة العظمى في تقدير كثافة الهو اء خلال ساعات السطوع ، و وعلى متوسط درجة

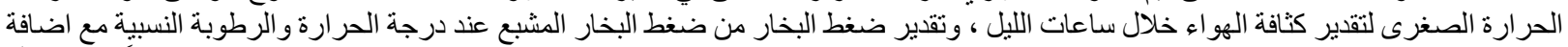

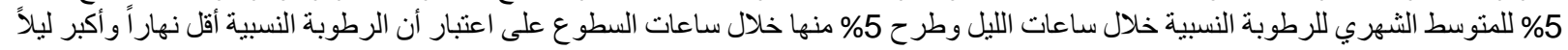

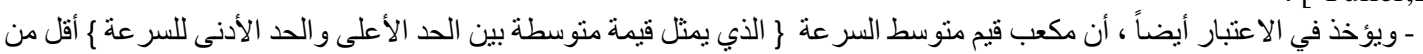

[ [ Tuller,2007.p4 ]

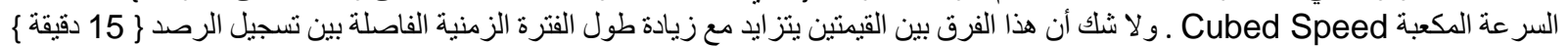

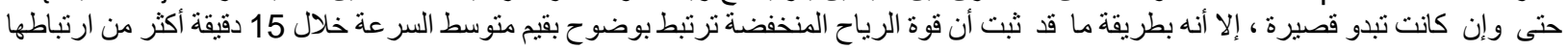

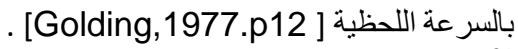

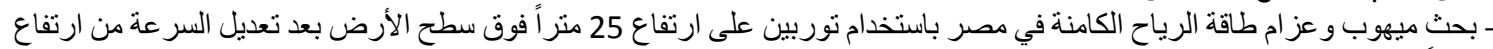

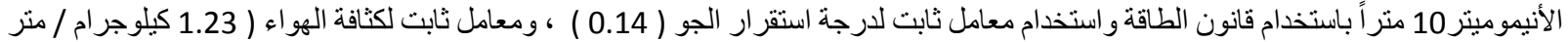

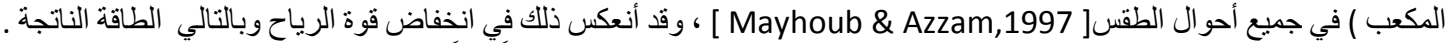

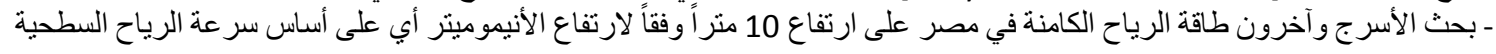

. [ El-Asrag \& Others,2000]

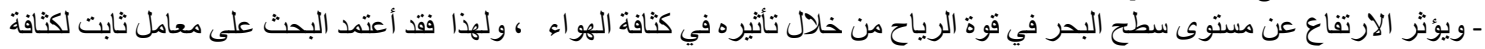

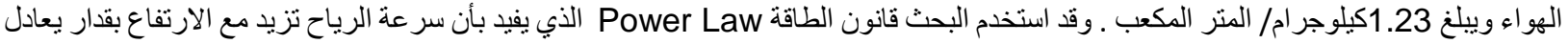

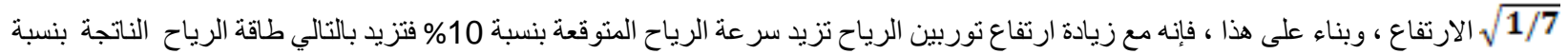

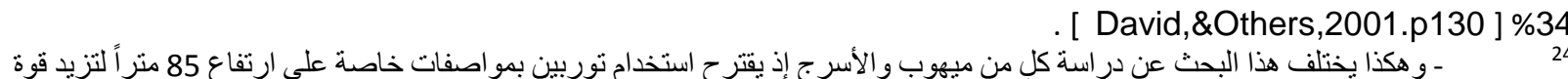

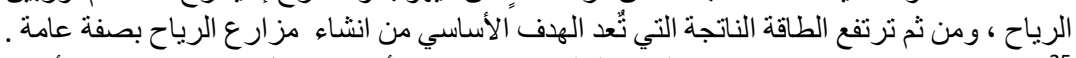

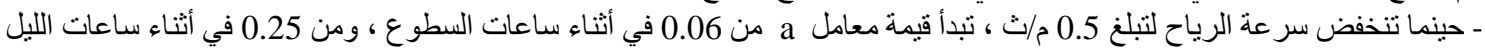

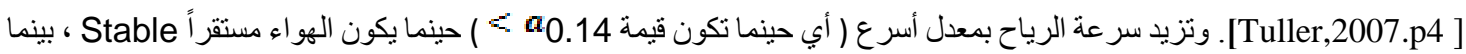

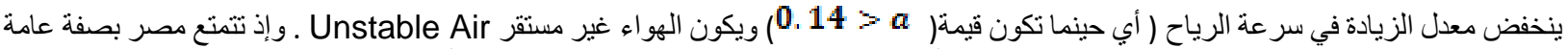

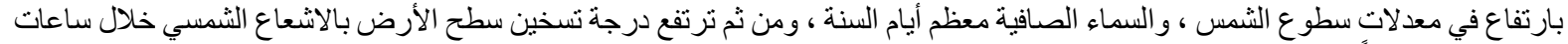

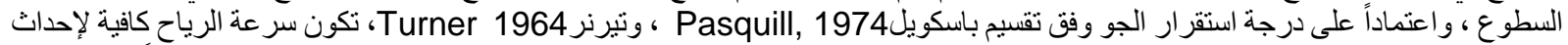

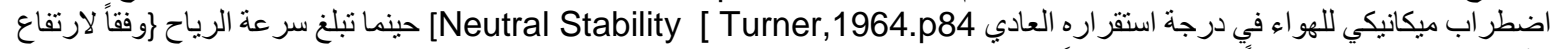

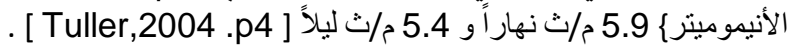

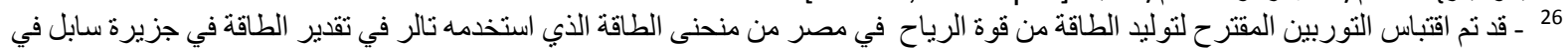

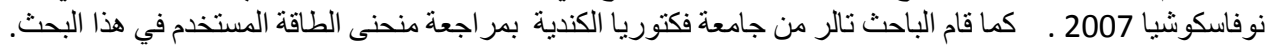

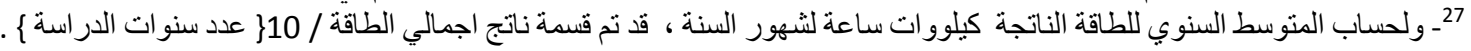


1995 / 2004 ؛ و ـ ويتم حساب هذه الطاقة بضرب تكرار سرعة الرياح الساعية بعد تصحيحها لارتفاع 85 متراً فوق مستوى سطح

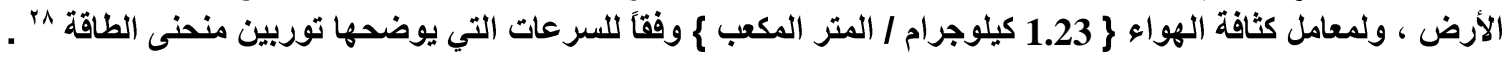

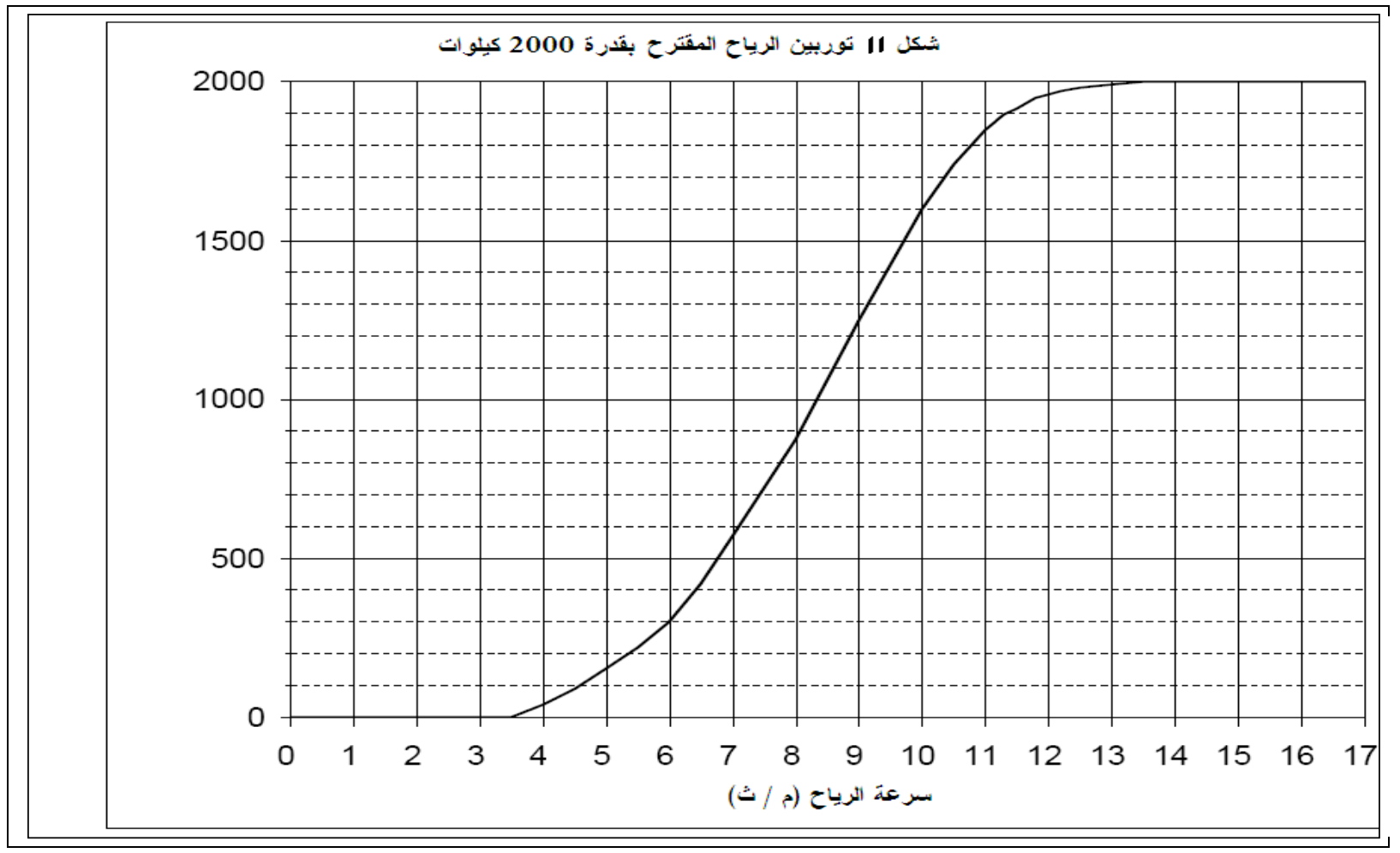

ويمكن تحليل نتائج تطبيق هذا المنهج على البيانات المستخدمة على النحو التالي : 1 - امكانيات طاقة الرياح الفصلية والثهرية والسنوية عند منتصف الليل :

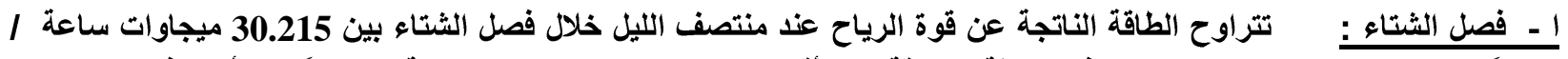

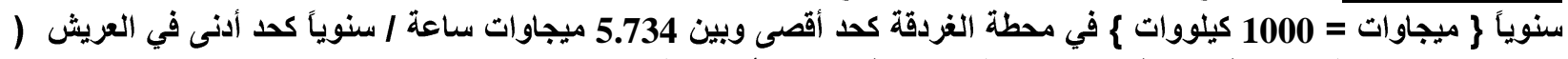

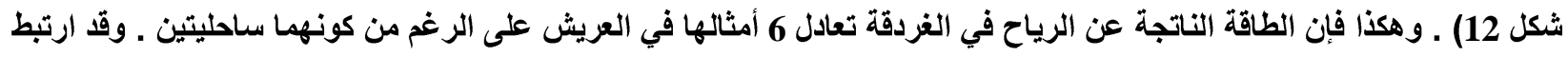

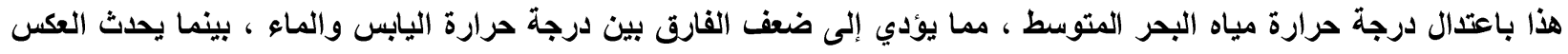

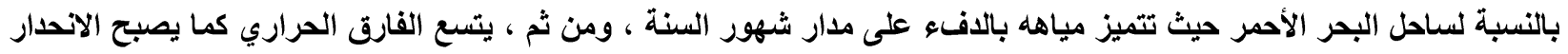

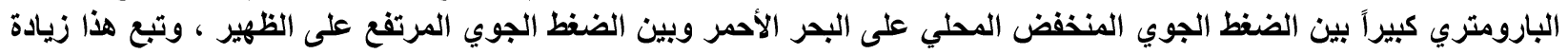

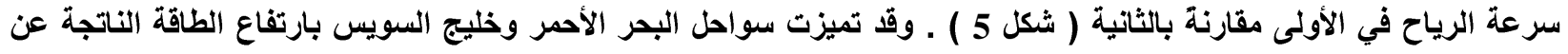

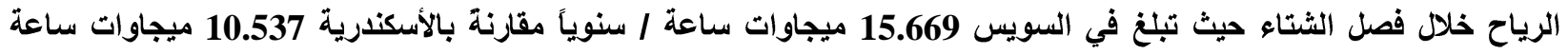

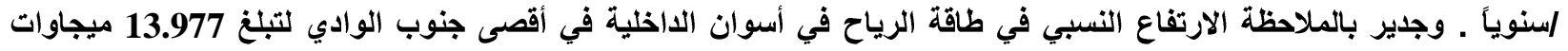

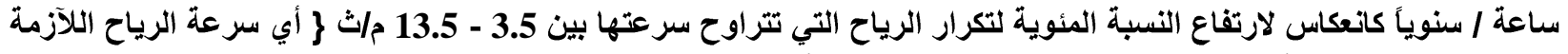

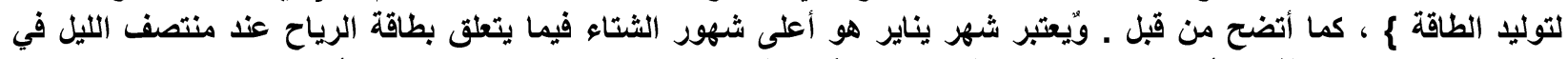

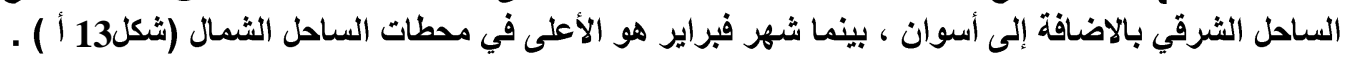

28 ـ وقد تم تعديل البيانات بهدف التعويض عن البيانات المفقودة ، فضلاً عن تعويض سر عة الرياح المتغيرة ج التي تشير إلى عدم وجود سر عة محددة

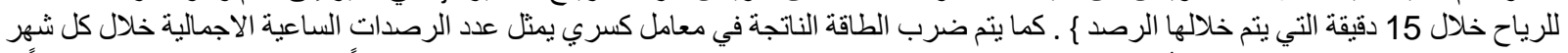

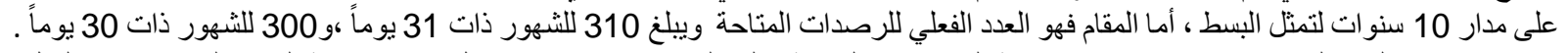

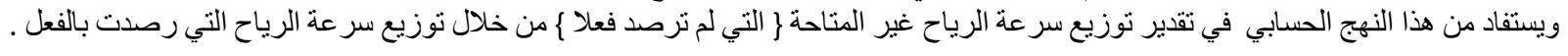




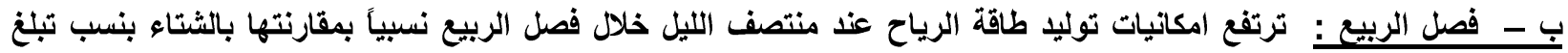

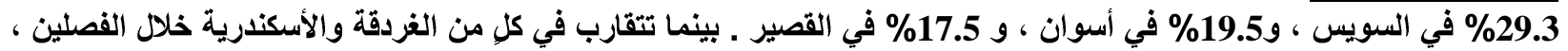

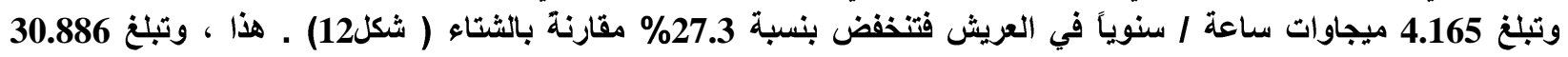

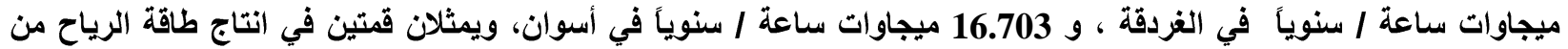

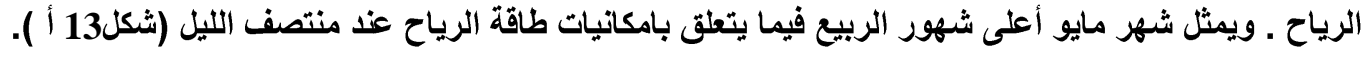

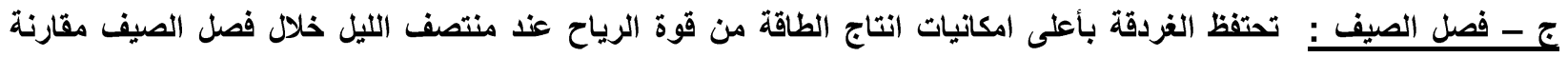

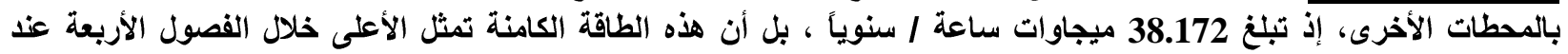

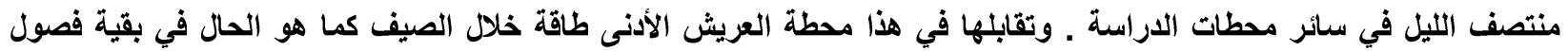

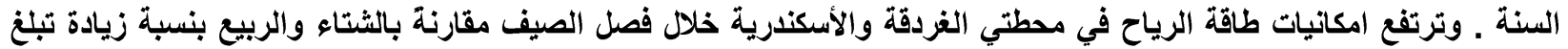

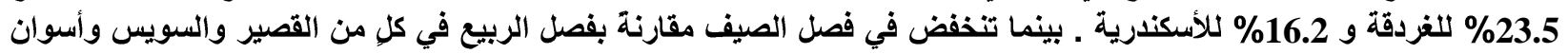

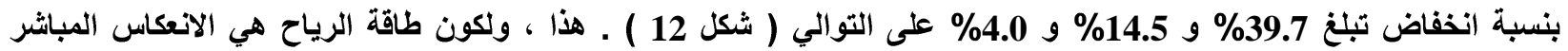

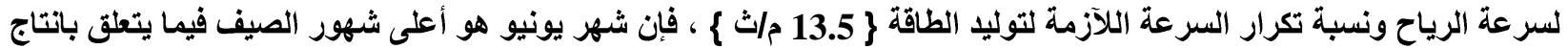
الطاقة في جميع المحطات خلال مدة الدراسة ( شكل الرئ 13 أ ) ) .

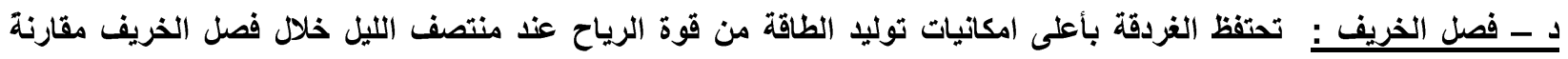

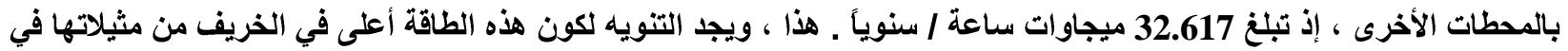

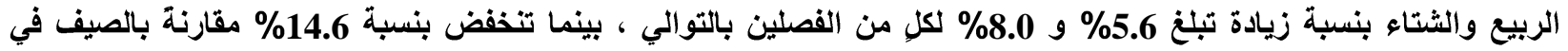

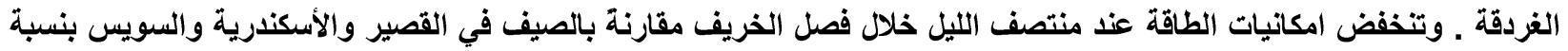

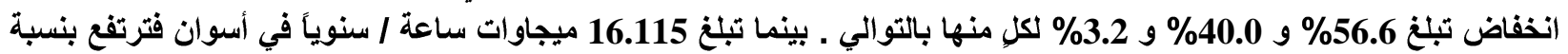
8.4 مقارنة بفصل الصيف (ثكل 12) ـ ويماثل شهر سبتمبر خلال الخريف شهر يونيو ، إذ يعد هو الأعلى فيما يتعلق بامكانيات

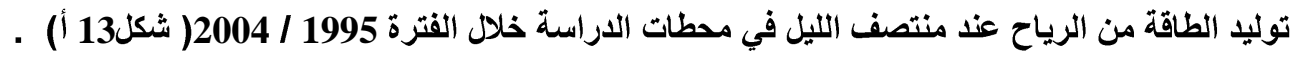

2- امكانيات طاقة الرياح الفصلية والثهرية والسنوية عند الظهيرة :

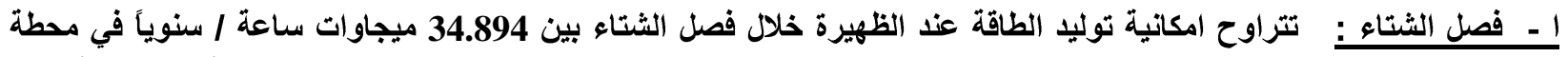

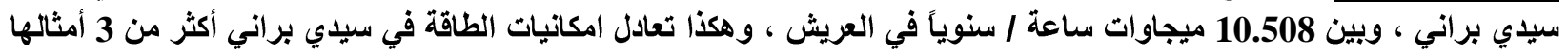

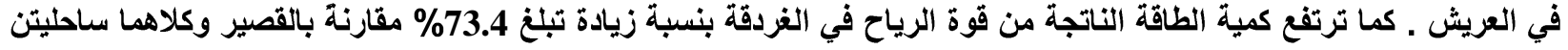

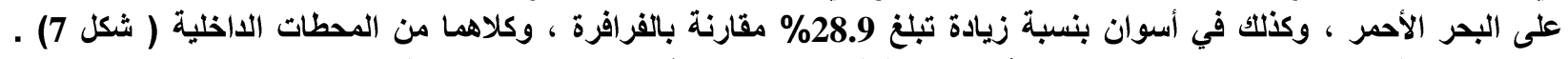

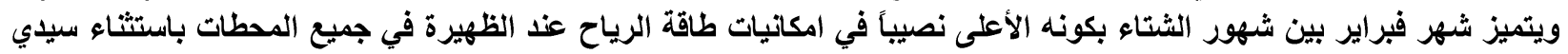

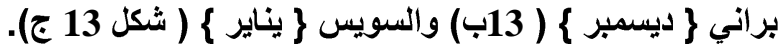




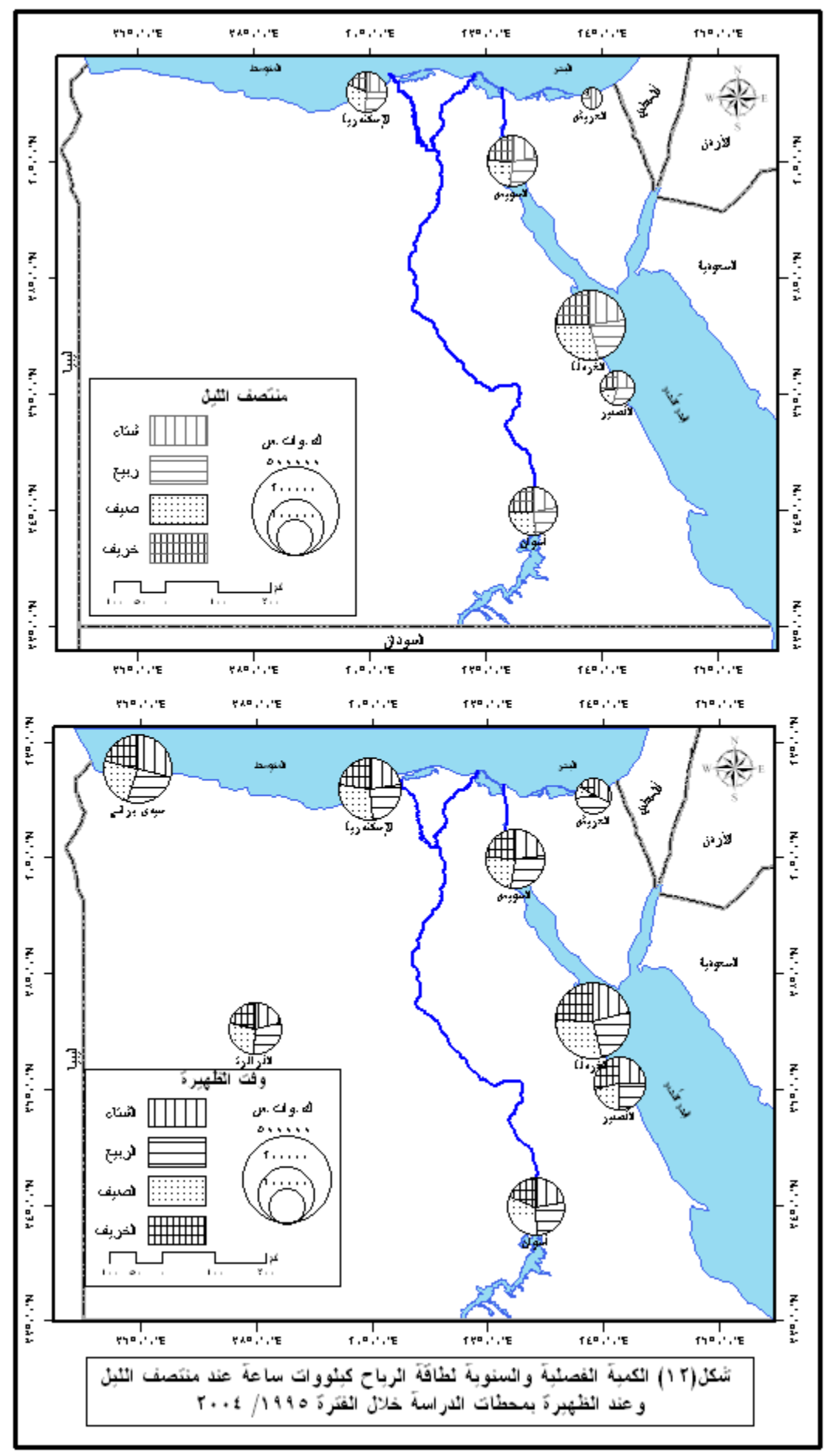

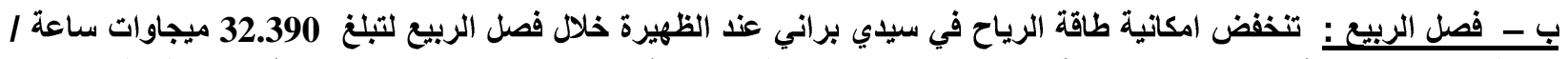

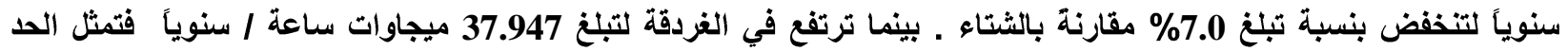

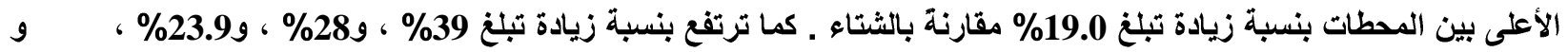

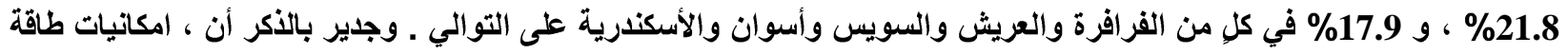

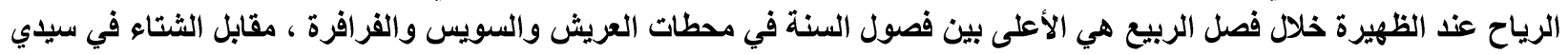


براني فقط ( شكل 12). وترتفع طاقة الرياح عند الظهيرة في شهر مارس في كلي من العريش والقصير والغردقة ، وفي شهر أبريل في

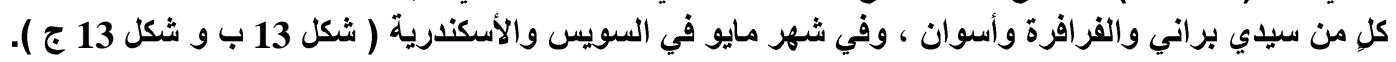

جـ فصل الصيف: يعتبر فصل الصيف هو أعلى فصول السنة فيما يتعلق بامكانيات توليد الطاقة من قوة الرياح عند الظهيرة في كل

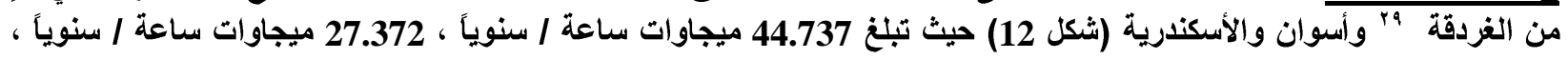

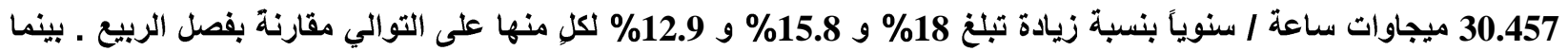

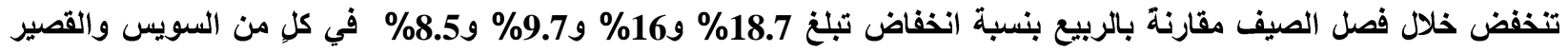

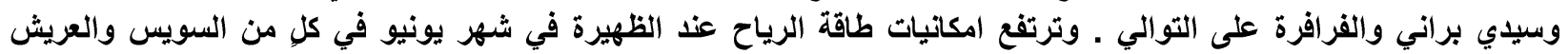

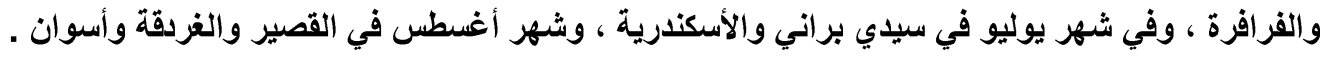

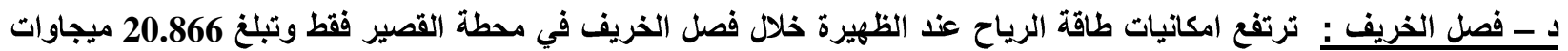

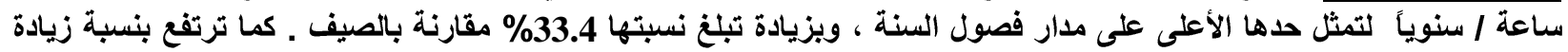

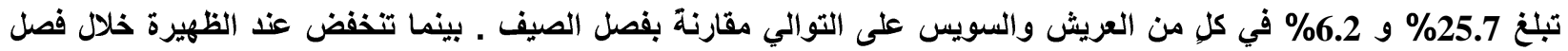

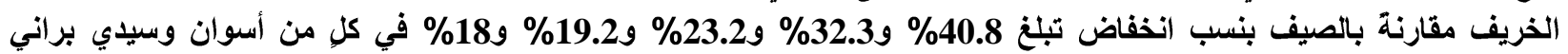

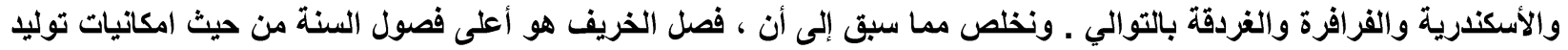

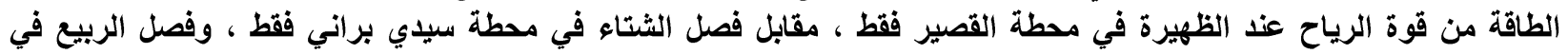

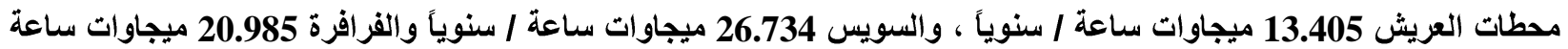

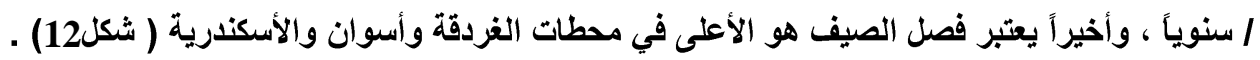

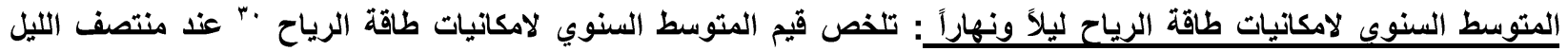

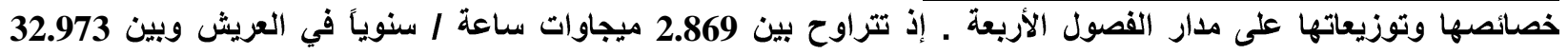

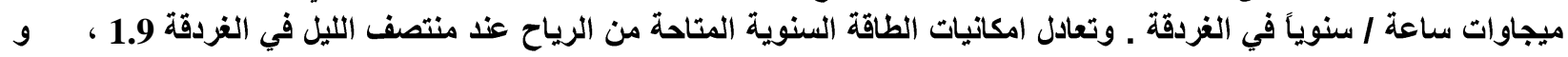

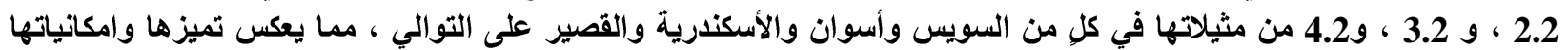

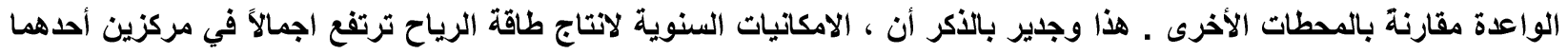

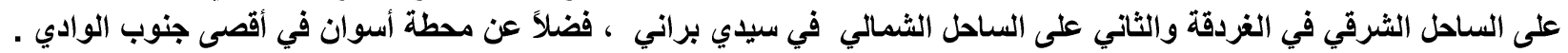

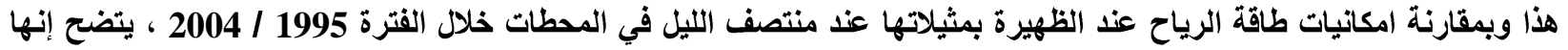

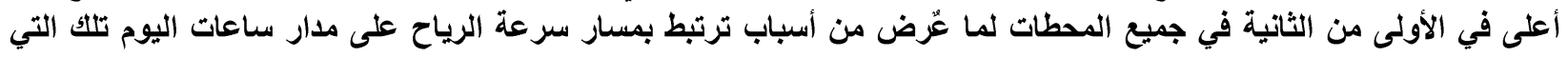

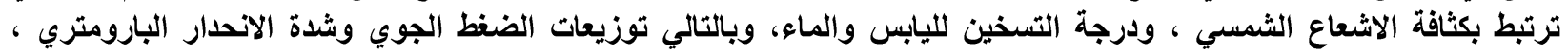

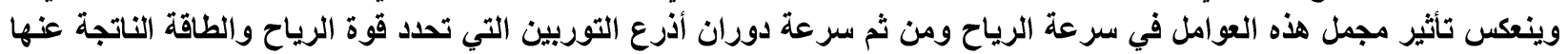
( ) جدول 2 ) (

29. ـتحليل العلاقة الارتباطية بين سر عة الرياح وطاقة الرياح في محطة الغردقة لكونها تتمتع بأعلى امكانيات نوليد الطاقة من قوة الرياح ليلاً ونهاراً

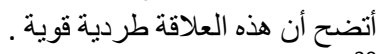

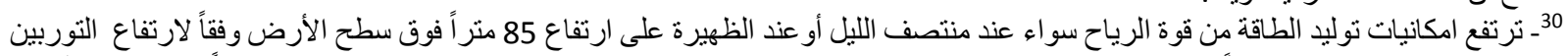

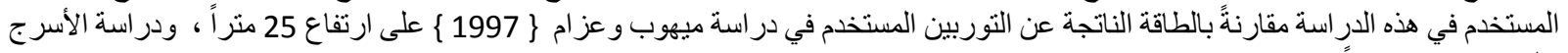

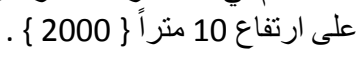



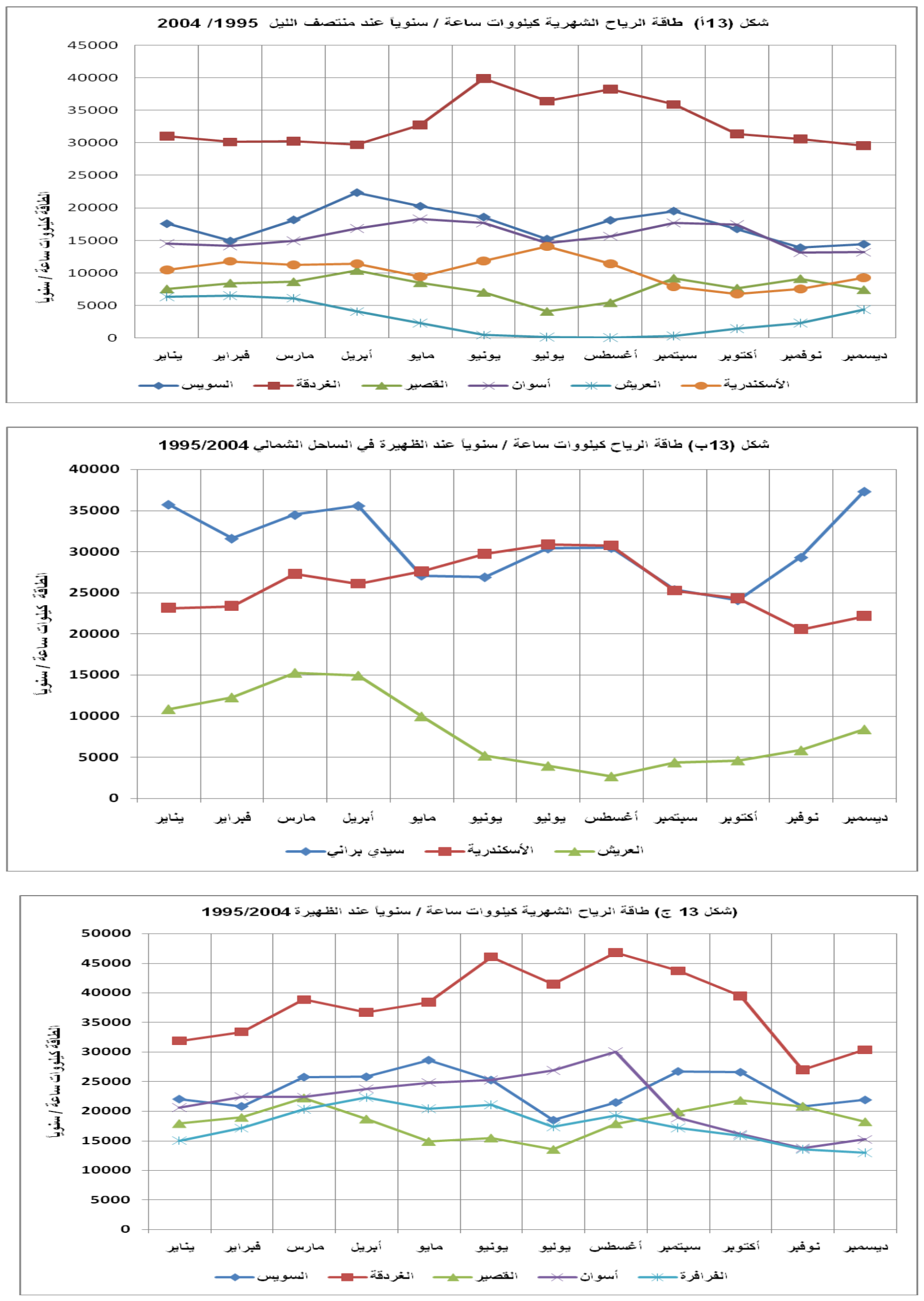


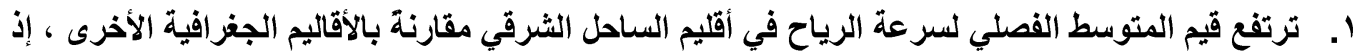

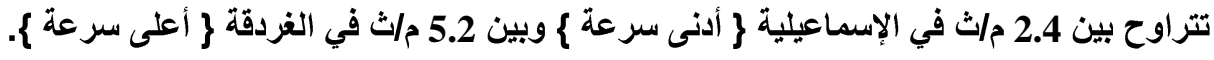

r. ترتفع محصلة جريان الرياح على سواحل البحر الأحمر وخليجي العقبة والسويس لتصل حدها الأعلى في الغردقة

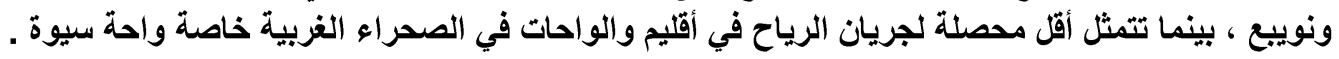

r. تتمثل القمة الثهرية لسرعة للرياح في شهور فبراير ومارس ويونيو ، بينما تتخفض السرعة اجمالاً خلال شهور فصل الخريف . ؛. تتميز الغردقة بأعلى قيم متوسط سنوي لسرعة الرياح عند منتصف الليل وتليها محطة أسوان . ه. ترتفع سرعة الرياح عذ منتصف الليل على ساحل البحر الأحمر بصفة عامة مقارنة بساحل البحر المتوسط ،

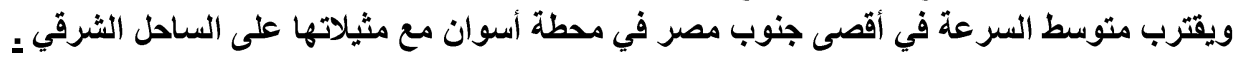

T. . ترتفع قيم متوسط سرعة الرياح عند الظهيرة مقارنة بمنتصف الليل في جميع المحطات على مدار السنة . V. . تتراوح قيم المتوسط السنوي لسرعة الرياح عند الظهيرة بين 3.8 م/ث في العريش و 7.6 م/ث في الغردقة .

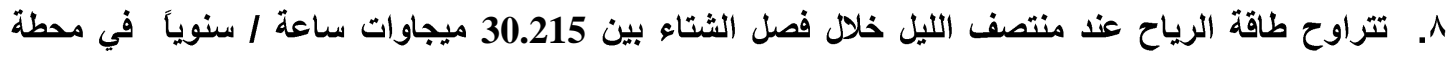

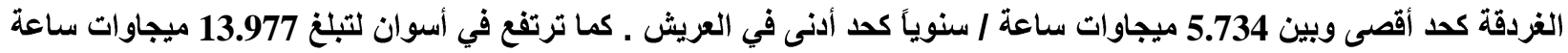

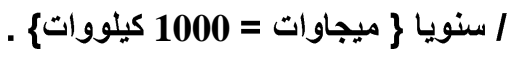

9. . ترتفع امكانيات طاقة الرياح عند منتصف الليل خلال فصل الربيع نسبياً بمقارنتها بالثتاء بنسب تبلغ 29.3\% في

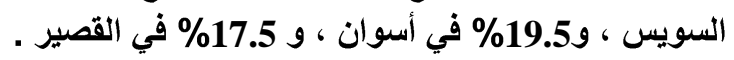

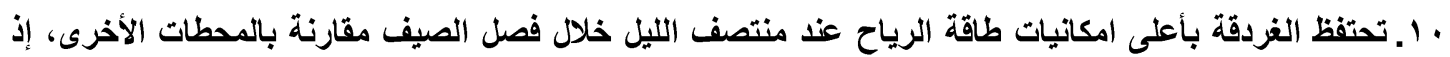

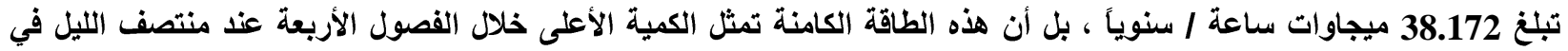

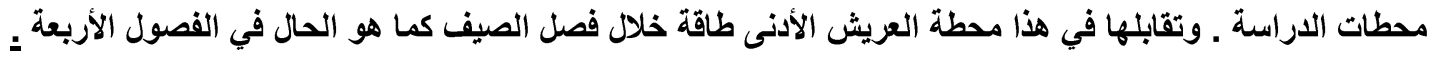

1 أ تعادل امكانيات الطاقة السنوية من قدرة الرياح عند منتصف الليل في الغردقة 1.9 ، و 2.2 ، و 3.2 ، و4.2 من

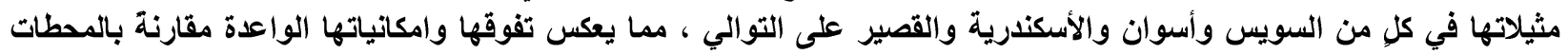

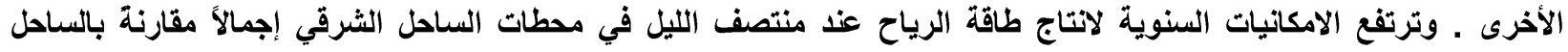
الثمالي .

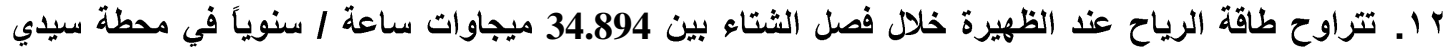

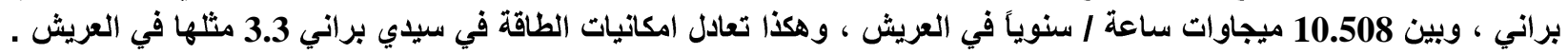

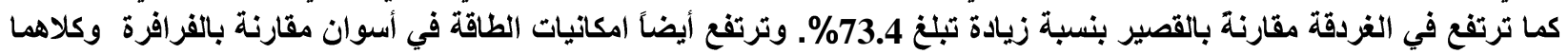

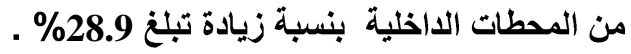

با 1. تعتبر امكانيات طاقة الرياح عند الظهيرة خلال فصل الربيع هي الأعلى بين فصول السنة في محطات العريش والسويس والفرافرة ، بينما هي كذلك خلال الثتاء في سيدي براني فقط ، وخلال الصيف في كلٍ من الغردقة وأسوان فئ فئ والأسكندرية .

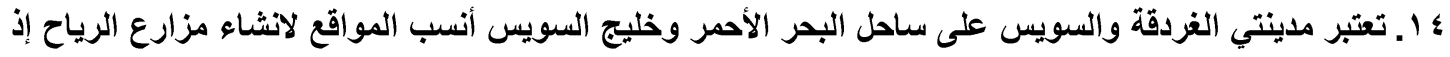

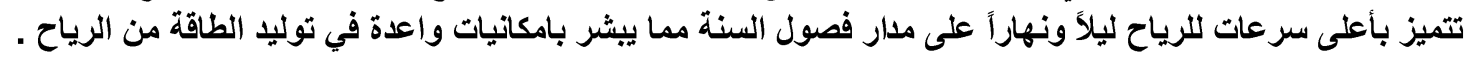

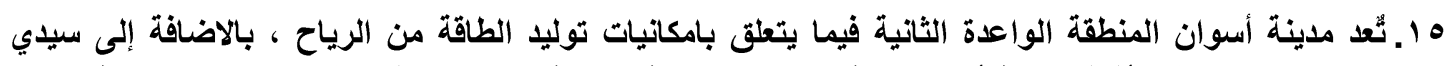

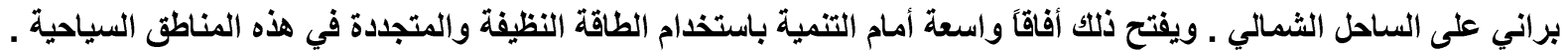


> إجراء المزيد من الأبحاث الجغرافية فيما يتعلق بسرعة الرياح وامكانيات استخدامها في توليد الطاقة

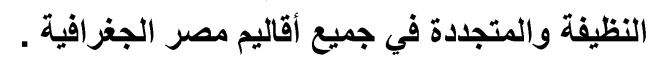

> نشر الوعي البيئي بجدوى استخدام الطاقة النظيفة للحفاظ على سلامة البيئة وصحة الإنسان .

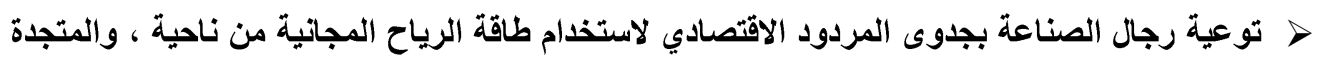

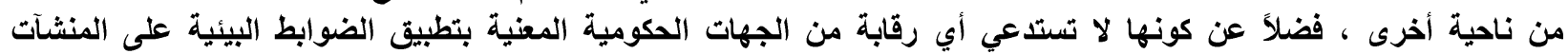

الصناعية .

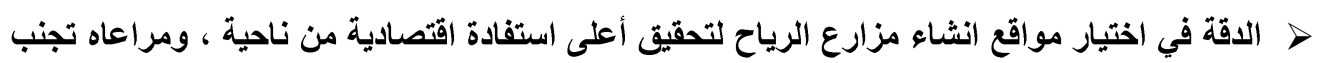

مسارات الطيور المهاجرة والحفاظ على المظهر البيئي لتجنب التشويه الجمالي والتلوث الضوضاعيأي من ناحية أخرى .

جدول ( 1 ) خصائص محطات الاراسة

\begin{tabular}{|c|c|c|c|c|c|}
\hline وصف طبوغرافية المحطة & بالأنيموميتر & دولة شرقاً & خط الط & دائرة العرض شمالاً & المحطة \\
\hline ترتفع المحطة 23.71 متراً فوق مستوى سطح البحر . & & 25 & 54 & 3137 & $\begin{array}{c}\text { سيدي براني } \\
\text { \&\# }\end{array}$ \\
\hline 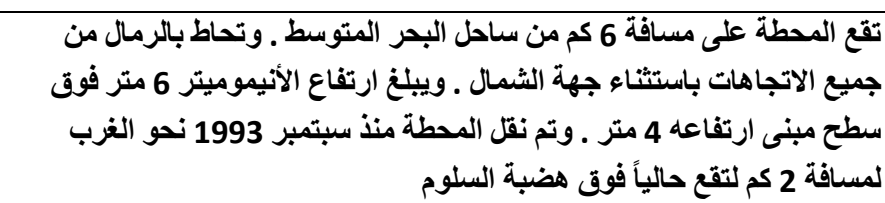 & 9 & 25 & 08 & $31 \quad 34$ & 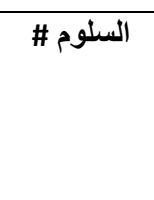 \\
\hline 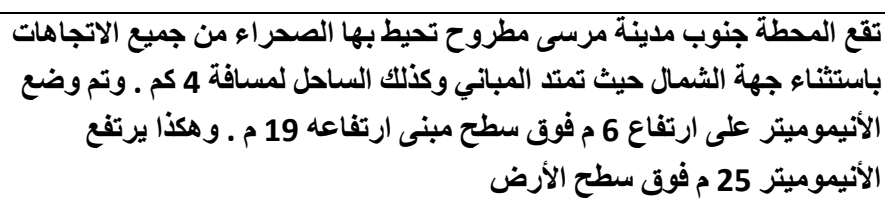 & 6 & 27 & 13 & 3120 & مطروح \# مرسى \\
\hline 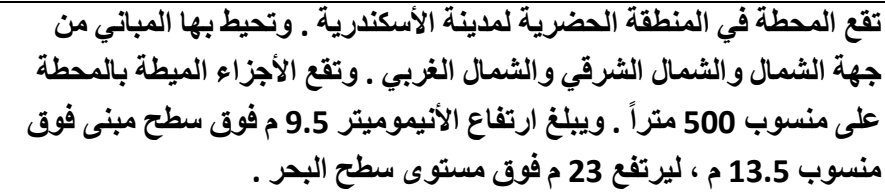 & 9.5 & 29 & 57 & $\begin{array}{ll}31 & 11\end{array}$ & الأسكندرية \\
\hline تقع المحطة على ارتفاع 6.7 متر فوق مستوى سطح البحر . & & 34 & 14 & $31 \quad 16$ & رفح \# \\
\hline 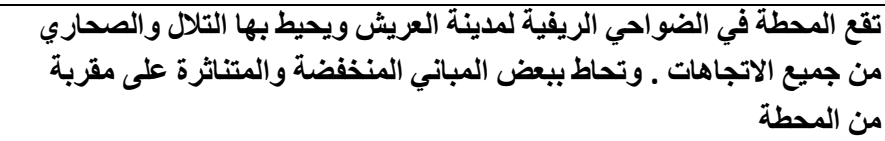 & 8.5 & 33 & 49 & 3104 & العريش \\
\hline 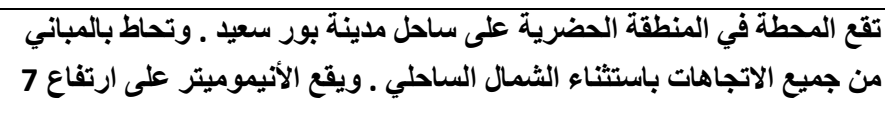 & 7 & 32 & 14 & $31 \quad 16$ & بور سعيد \\
\hline
\end{tabular}




\begin{tabular}{|c|c|c|c|c|c|c|}
\hline م فوق مبنى ارتفاعه 4 م ، ليبلغ ارتفاعه 11 م . & & & & & & \\
\hline تقع المحطة على ارتفاع 1.00 متر فوق مستوى سطح البحر . & & 31 & 06 & 31 & 33 & بلطيم \# \\
\hline تقع المحطة على ارتفاع 1.98 متر فوق مستوى سطح البحر . & & 31 & 49 & 31 & 25 & دمياط \\
\hline 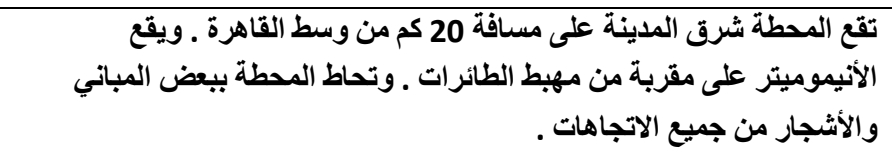 & 9.5 & 30 & 54 & 30 & 06 & 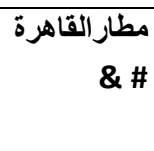 \\
\hline تقع المحطة على ارتفاع 4.25 متر فوق مستوى سطح البحر . & & 31 & 27 & 31 & 00 & المنصورة"\# \\
\hline تقع المحطة على ارتفاع 225.7 متر فوق مستوى سطح البحر . & & 33 & 46 & 30 & 27 & الحسنة \# \\
\hline تقع المحطة على ارتفاع 320.9 متر فوق مستوى سطح البحر . & & 32 & 45 & 30 & 58 & بئز العبد \# \\
\hline تقع المحطة على ارتفاع 320.0 متر فوق مستوى سطح البحر . & & 33 & 09 & 30 & 25 & المليز \# \\
\hline 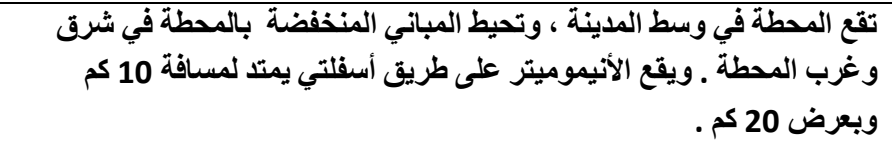 & 9.5 & 32 & 14 & 30 & 35 & الإسماعيلية \\
\hline 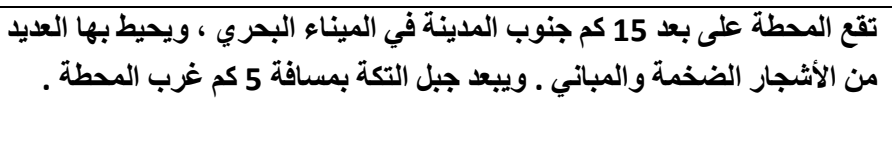 & 10 & 32 & 28 & 29 & 25 & $\begin{array}{l}\text { السويس } \\
\text { \& \# }\end{array}$ \\
\hline تقع المحطة على ارتفاع 401.2 متر فوق مستوى سطح البحر . & & 33 & 44 & 29 & 54 & 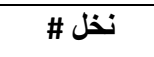 \\
\hline تقع المحطة على ارتفاع 320.0 متر فوق مستوى سطح البحر . & & 34 & 41 & 28 & 58 & نويبع \# \\
\hline ترتفع المحطة 9 متر فوق مستوى سطح البحر . & & 33 & 37 & 28 & 14 & الطور \# \\
\hline 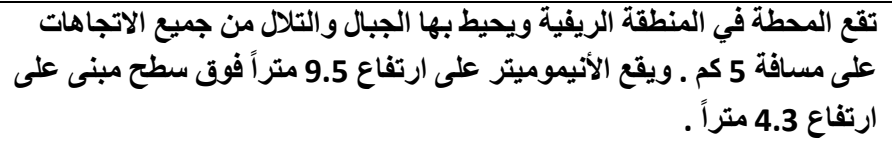 & 10 & 34 & 03 & 28 & 40 & ساترين \\
\hline 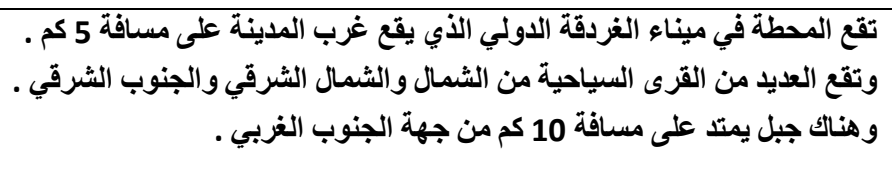 & 9 & 33 & 48 & 27 & 11 & الغردقة \\
\hline 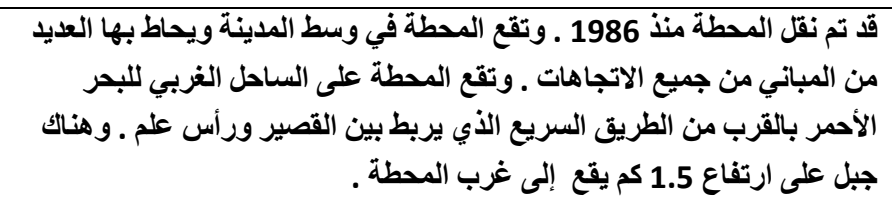 & 10 & 34 & 16 & 26 & 06 & القصيز \\
\hline 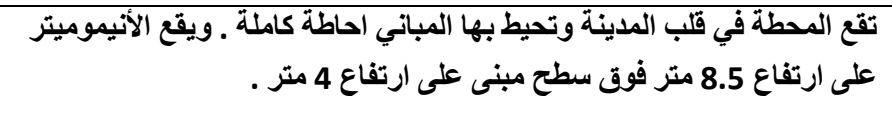 & 10 & 25 & 19 & 29 & 11 & سيوة \# سيو \\
\hline
\end{tabular}




\begin{tabular}{|c|c|c|c|c|c|c|}
\hline تقع المحطة على ارتفاع 15.00 متر فوق مستوى سطح البحر . & & 28 & 52 & 28 & 20 & البحرية \# \\
\hline تقع المحطة على ارتفاع 37.15 متر فوق مستوى سطح البحر . & & 30 & 44 & 28 & 05 & 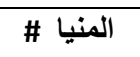 \\
\hline 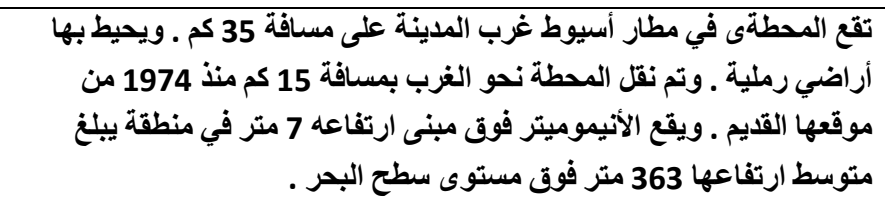 & 18.6 & 31 & 00 & 27 & 03 & أسيوط \# \\
\hline ترتفع المحطة 82.20 متراً فوق مستوى سطح البحر . & & 27 & 58 & 27 & 03 & $\begin{array}{r}\text { الفرافرة } \\
\text { \&\# }\end{array}$ \\
\hline ترتفع المحطة 77.72 متراً فوق مستوى سطح البحر . & & 32 & 44 & 26 & 10 & ق قنا \\
\hline 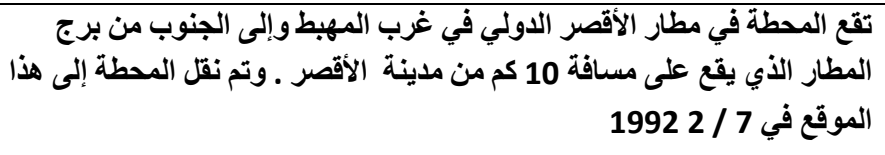 & 10 & 32 & 41 & 25 & 40 & $\begin{array}{c}\text { الأقصر } \\
\text { \# }\end{array}$ \\
\hline 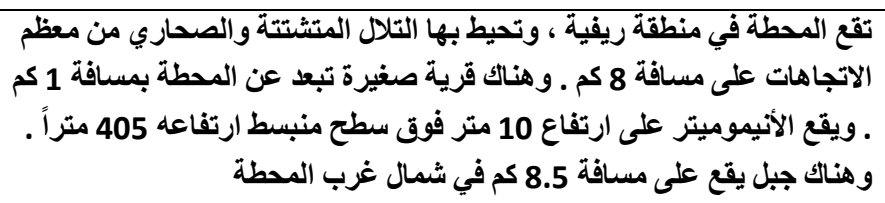 & 8 & 28 & 58 & 25 & 30 & الاخلة \# \\
\hline 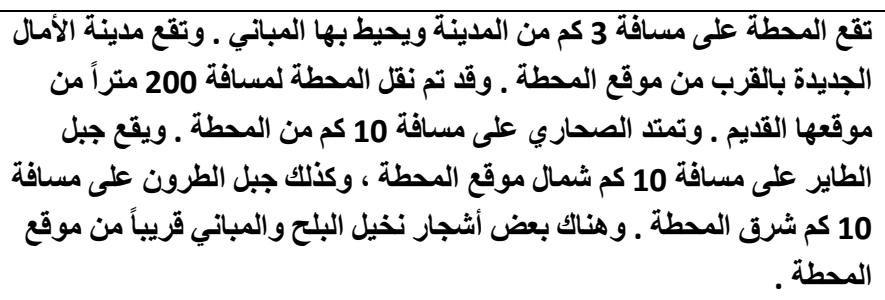 & 11.5 & 30 & 32 & 25 & 27 & | الخارجة | \\
\hline 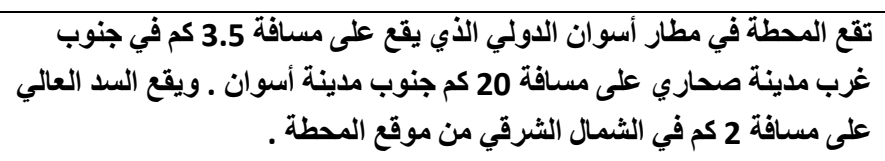 & 6 & 32 & 49 & 23 & 58 & \&\#وان \\
\hline ترتفع المحطة 61.36 متراً فوق مستوى سطح البحر . & & 31 & 42 & 26 & 34 & 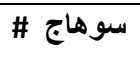 \\
\hline ترتفع المحطة 82.20 متراً فوق مستوى سطح البحر . & & 35 & 28 & 23 & 57 & رأس بناس \\
\hline
\end{tabular}

• ارتفاع الأنيموميتر فوق مستوى سطح الأرض بالمتر .

• 1980 /

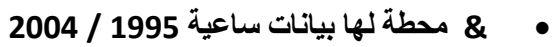

المصادر :

1 - الهيئة العامة للأرصاد الجوية ، جمهورية مصر العربية : إدارة المحطات السطحية ، بيانات غير منثورة . 
.Egyptian Meteorological Authority, Cairo, Egypt, October 20-2

جدول ( 2 )

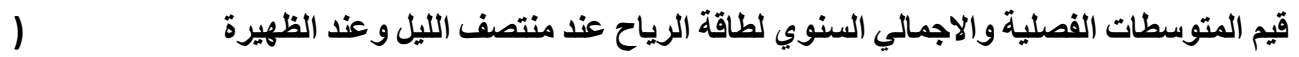
كيلووات ساعة / سنوياً ) خلال مدة الاراسة 1995 / 1904

\begin{tabular}{|c|c|c|c|c|c|c|}
\hline الاجمالي & الخريف & الصيف & الربيع & الثتاء & المحطة & التوقيت \\
\hline 123474.5 & 22283.18 & 37389.79 & 32189.39 & 31612.17 & الأسكندرية & منتصف الليل \\
\hline 34430.95 & 4061.48 & 667.9 & 12497.52 & 17204.05 & العريش & منتصف الليل \\
\hline 210050.8 & 50279.1 & 51973.6 & 60788.7 & 47009.4 & السويس & منتصف الليل \\
\hline 93889.55 & 26089.47 & 16657.4 & 27632.77 & 23509.91 & القصير & منتصف الليل \\
\hline 395679.4 & 97853.67 & 114517.7 & 92660.98 & 90647.03 & الغردقة & منتصف الليل \\
\hline 188337.1 & 48346.78 & 47945.95 & 50111.97 & 41932.38 & أسوان & منتصف الليل \\
\hline الاجمالي & الخريف & الصيف & الربيع & الثتاء & المحطة & التوقيت \\
\hline 368404.6 & 78772.04 & 87779.18 & 97170.48 & 104682.9 & براني & الظهيرة \\
\hline 311135.5 & 70130.38 & 91371.36 & 80957.21 & 68676.56 & الأسكندرية & الظهيرة \\
\hline 98328.31 & 14805.2 & 11780.37 & 40215.92 & 31526.82 & العريش & الظهيرة \\
\hline 279314.2 & 69201.05 & 65184.51 & 80202.28 & 64726.35 & السويس & الظهيرة \\
\hline 220453.6 & 62598 & 46913.39 & 55846.53 & 55095.7 & القصير & الظهيرة \\
\hline 453589.8 & 110010.8 & 134213.7 & 113841.4 & 95523.85 & الغردقة & الظهيرة \\
\hline 212273.8 & 46567.49 & 57612.55 & 62957.53 & 45136.23 & الفرافرة & الظهيرة \\
\hline 259816.9 & 48592.48 & 82117.48 & 70896.7 & 58210.19 & أسوان & الظهيرة \\
\hline
\end{tabular}

المصدر :

نتائج تحليل بيانات سرعة الرياح الساعية وتطبيق معادلات الطاقة على بيانات المحطات خلال مدة الدراسة 1995 - 2004 


\section{المراجع والمصادر العربية :}

1. الأوابك : التقرير الأحصائي السنوي لعام 2004 .

r. الأوابك : تقرير الأمين العام السنوي لعام 2004 ـ.

r. تريثر ، روبرت ( يوليو 2005 ) : حماية البيئة ـ ثلاثون عاماً من التقلم الأمريكي ، مركز تكنولوجيا الرياح

القومي ، مختبر الطاقة المتجدة القومي ، وزارة الخارجية الأمريكية .

؛. . الحسيني ، فتحي ( 2000) : دور الأرصاد الجوية في الطاقة الجديدة والمتجددة ، مجلة الأرصاد ، ص 9 - 15 . •. حنا ، كامل ( 1978 ) : مناخ جمهورية مصر العربية ، الهيئة العامة للأرصاد الجوية ، القاهرة .

4. . سالم ، طارق زكريا ( 1993 ) : : مناخ شبه جزيرة سيناء والساحل الثرقي لمصر ـ دراسة في الجغرافيا المناخية ، رسالة ماجستير غير منشورة ، كلية الآداب ، جامعة الزقازيق . V. شحادة ، نعمان ( 1983 ) : المناخ العملي ، الجامعة الأردنية ، الأردن ، عمان . ^. علي ، عبد القادر عبد العزيز ( 1993 ) : الغلاف الجوي والطقس والمناخ ، مترجم : ص ـ ـ ـ بيري ، وص ـ ـ ي . شوري ، المجلس الأعلى للثقافة ، مطابع الأميرية ، القاهرة .

9. فايد ، يوسف عبد المجيد ( 1971 ) : جغرافية المناخ والنبات ، دار النهضة العربية للطباعة والنشر ، بيروت . ـ ا فايد ، يوسف عبد المجيد وآخرون ( 1994 ) : مناخ مصر ، دار النهضة العربية ، القاهرة . 1 الإل الفقي ، أحمد عبد الحميد ( 1999 ) : الرياح في مصر - دراسة في الجغرافيا المناخية ، رسالة ماجستير غير منشورة ، كلية الآداب ، جامعة عين شمس ،

ب ا ـ الهيئة العامة للأرصاد الجوية ( 1996 ) : الأطلس المناخي لمصر ، الهيئة المصرية العامة للمساحة ، مصر . 1 أ الهيئة العامة للأرصاد الجوية ، جمهورية مصر العربية : بيانات مناخية غير منشورة لمحطات مناخية مختارة للفترة 1980 - 2004 م .

ـ ا. وزارة الكهرباء والطاقة ، جمهورية مصر العربية : التقرير السنوي لوزارة الكهرباء والطاقة عام 2005 ـ 


$$
\begin{aligned}
& \text { ه } 1 \text { ـ يوسف ، عبد العزيز عبد اللطيف ( } 1998 \text { ) : التباين المناخي بين السواحل المصرية ـ دراسة جغرافية ، المجلة } \\
& \text { الجغرافية العربية ، الجمعية الجغرافية المصرية ، العدد الثاني والثلاثون ، ص } 205 \text { ـ } 244 \text { ـ } 249 \\
& \text { ، } 1 \text { ـ يوسف ، عبد العزيز عبد اللطيف ( 2000) : التباين المناخي على ثلاثة محاور طولية في مصر ، مجلة بحوث } \\
& \text { كلية الآداب ، جامعة المنوفية ، العدد الرابع . } \\
& \text { المراجع والمصادر غير العربية: }
\end{aligned}
$$

1. David, Macaulay (1999): New Way Things Work, Houghton Mifflin Company, Boston, pp. 41 - 44.

2. David, Sharpe \& Others, (2001): Wind Energy Handbook, John Wiley and Sons, N.Y.

3. Egyptian Meteorology Authority (2000): Preliminary Wind Atlas for Egypt, National Laboratory, Roskilde, Denmark.

4. El-Asrag, A.M. \& Others (2000): Wind Atlas Project for Egypt and its Benefits to Environment, 5th Conference Meteorology and Sustainable Development, 22 -24 February 2000, pp.10 20.

5. Golding, E. W. (1977): The Generation of Electricity by Wind Power, E. \& F. N. Spon, London.

6. Hennessey , J. P. Jr. (1977) : Some Aspects of Wind Power Statistics, Journal of Applied Meteorology, Vol.16.pp.119-128.

7. Mayhoub, A. B. \& Azzam, A. (1997): A survey on the Assessment of Wind Energy Potential in Egypt, Renewable Energy, vol.11, No.2, pp.235 - 247.

8. Oliver, John, (1981): Climatology - fundamental and Application, John Wiley and Sons, N.Y.

9. Salem, A. I. \& Others (1999): Wind Energy Potential over Egypt, $4^{\text {th }}$ Conference Meteorology and Sustainable Development, 7 - 9 March, pp. 148 - 162.

10. Stringer, E. T. (1972): Techniques of Climatology, San Francisco.

11. Tuller, Stanton E. (2004):Trends in Measured Wind Speed - Sable Island, Paper Presented at the 2004 CAG Annual Meeting, Moncton, N. B.

12. Tuller, Stanton E. (2007): Temporal Variation in Annual Wind Power at Sable Island, Victoria University, Canada.

13. Turner, D.B. (1964): A Diffusion Model for an Urban Area, Journal of Applied Meteorology.

14. .www.climate-charts.com

15. WWW.Enviromental Benefits of Wind Energy.com 
16. WWW.Wind Power.com

17. WWW.Wind Renewable Energy.com

\section{ملخص البحث}

طاقة الرياح في مصر - دراسة في المناخ التطبيقي

مقدمة:

إذ تعتبر مشكلة توفير الطاقة من أهم المشكلات العصرية لكون مصادر الطاقة التقليدية غير

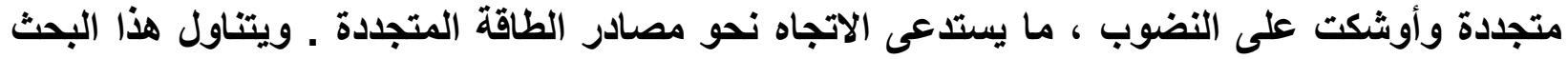

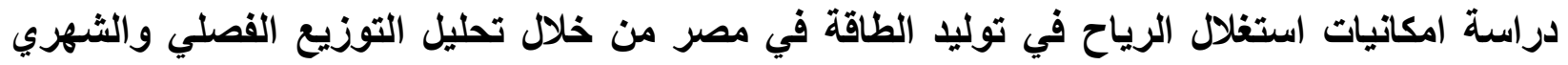

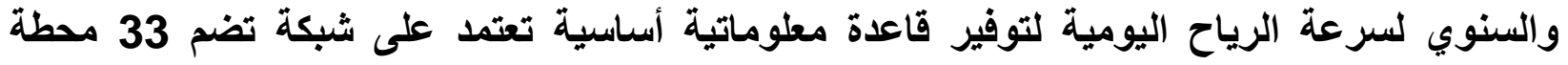

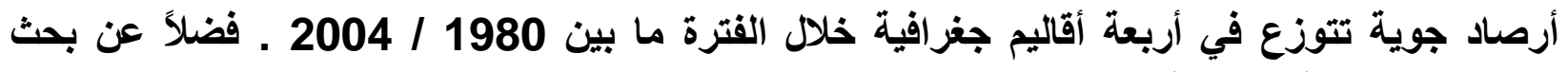

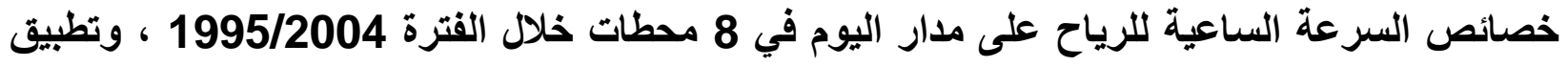

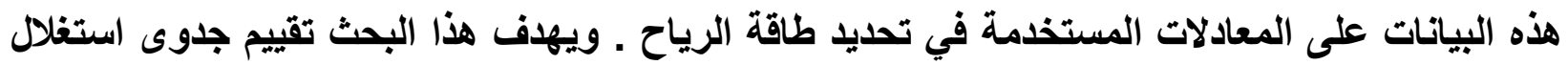

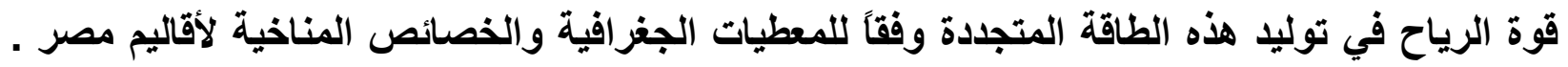

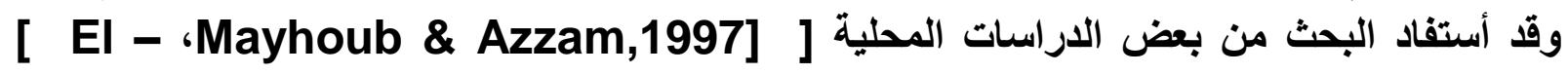

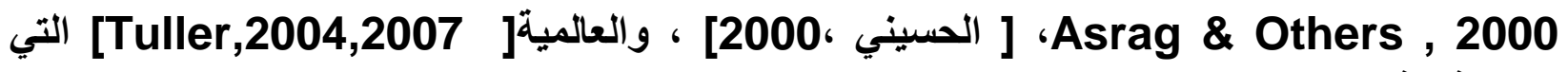
تبحث في ذات الموضوع .

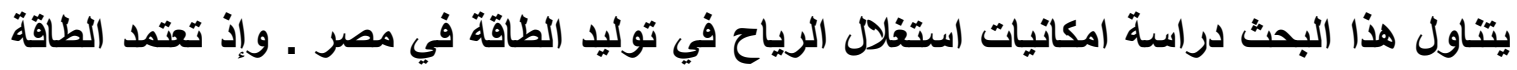

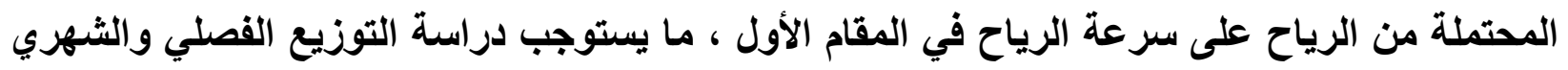

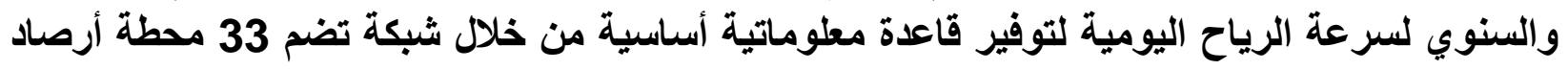

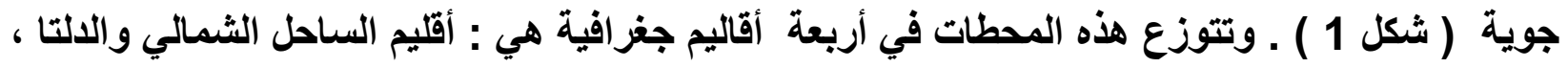

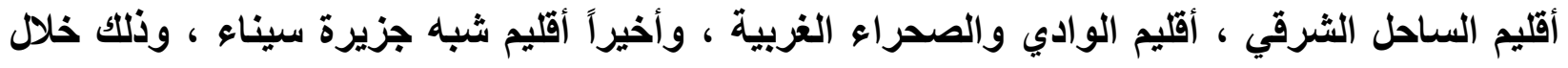

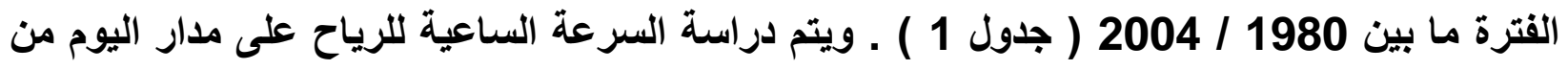

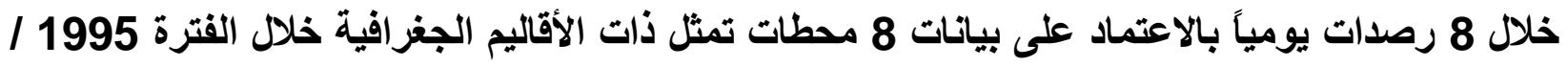


2004 ـ وقد أكتفى البحث بتطبيق معادلات الطاقة على سرعة الرياح عند منتصف الليل ووقت الظهيرة

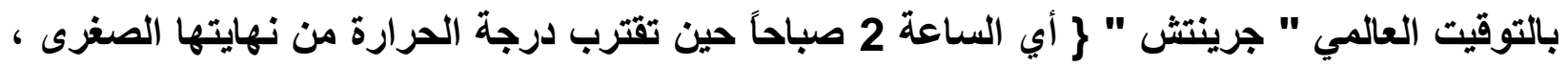

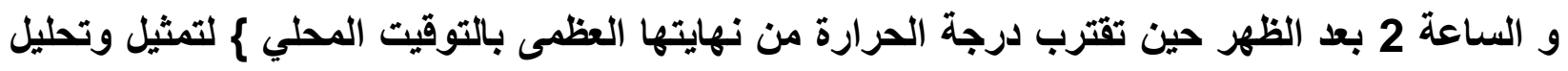
طاقة الرياح ليلاً ونهاراً .

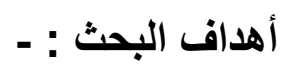

• تتبع وتحليل خصائص سرعة الرياح السطحية \} اليومية والساعية \{ في أقاليم مصر الجغرافية . • أقتراح نموذج التوربين المناسب لانتاج الطاقة وفقاً لخصائص سرعة الرياح في مصر . • تحديد أنسب المواقع لإنشاء مزارع الرياح لتوليد الطاقة في ضوء المعطيات الجغرافية . • تقييم جلوى استغلال طاقة الرياح المتجدة في مصر . ولتحقيق هذه الأهداف ، يتبع البحث تحليل العناصر التالية : > التوزيع الفصلي والثهري والسنوي للسرعة اليومية للرياح . ه محصلة الرياح سرعة واتجاهاً ، خصائص السرعة الساعية للرياح . > امكانيات طاقة الرياح الكامنة ليلاً ونهاراً .

النتائج :-

1. ترتفع قيم المتوسط الفصلي لسرعة الرياح في أقليم الساحل الثرقي مقارنة بالأقاليم

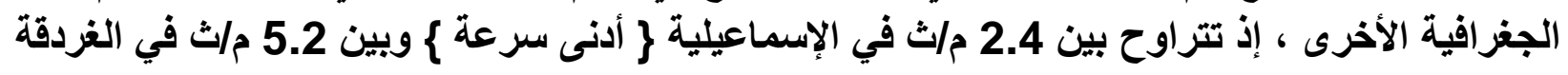

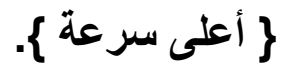

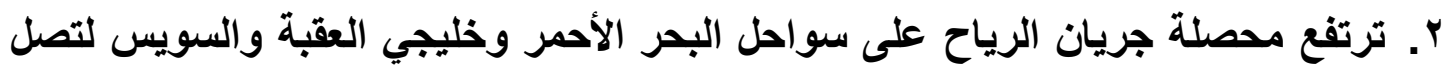

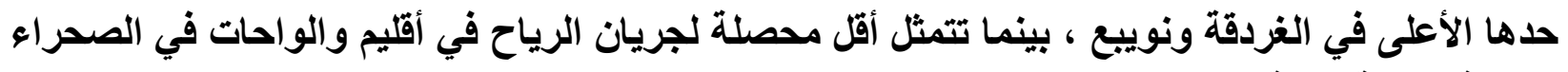

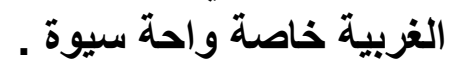

r. تتمثل القمة الثهرية لسرعة للرياح في شهور فبراير ومارس ويونيو ، بينما تنخفض السرعة اجمالاً خلال شهور فصل الخريف . ع. تتميز الغردقة بأعلى قيم متوسط سنوي لسرعة الرياح عند منتصف الليل وتليها محطة 
•. ترتفع سرعة الرياح عند منتصف الليل على ساحل البحر الأحمر بصفة عامة مقارنة بساحل البحر المتوسط ، ويقترب متوسط السرعة في أقصى جنوب مصر في محطة أسوان مع مثيلاتها على الساحل الثرقي .

7. ترتفع قيم متوسط سرعة الرياح عند الظهيرة مقارنة بمنتصف الليل في جميع المحطات على مدار السنة . V. تتراوح قيم المتوسط السنوي لسرعة الرياح عند الظهيرة بين 3.8 م/ث في العريش و 7.6 م/ث في الغردقة.

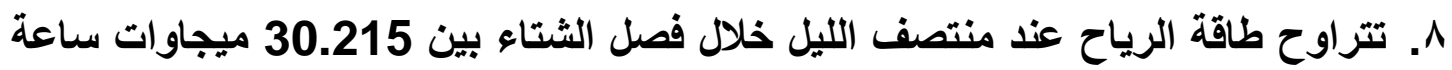

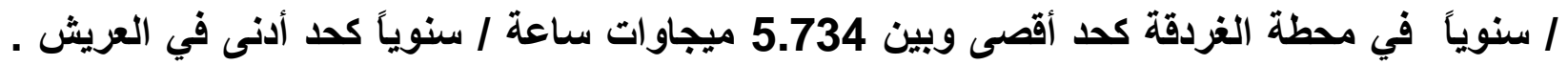

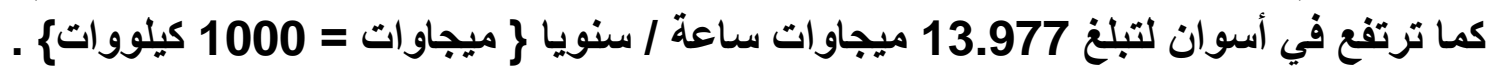
9. ترتفع امكانيات طاقة الرياح عند منتصف الليل خلال فصل الربيع نسبياً بمقارنتها بالشتاء

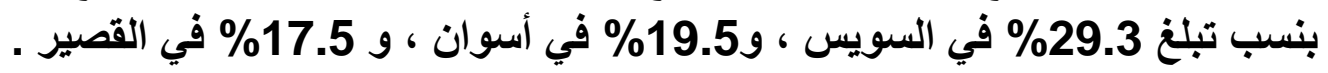

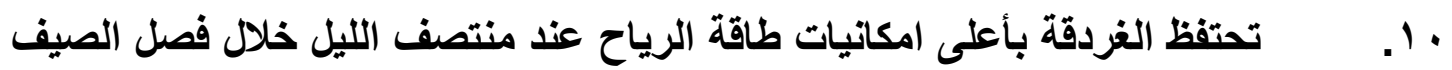

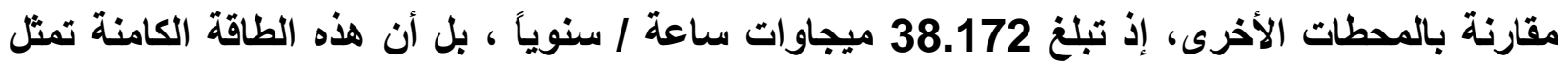

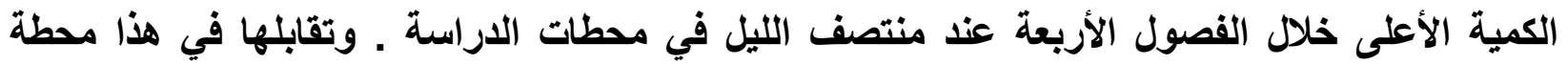
العريش الأدنى طاقة خلال فصل الصيف كما هو الحال في الفصول الأربعة .

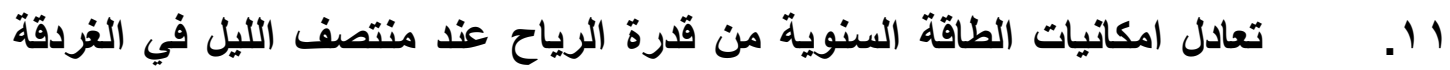

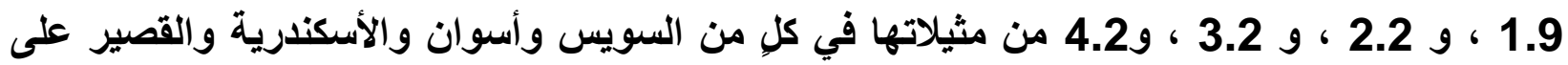

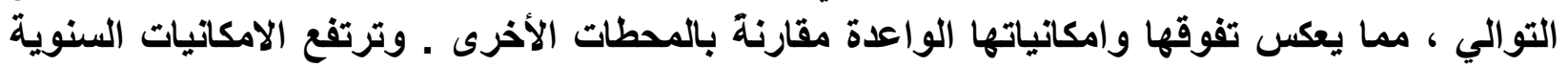

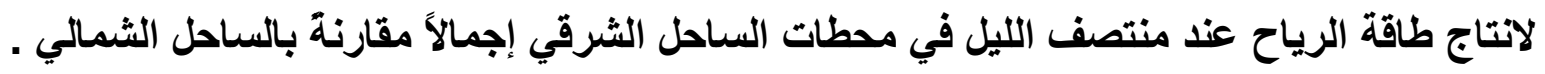

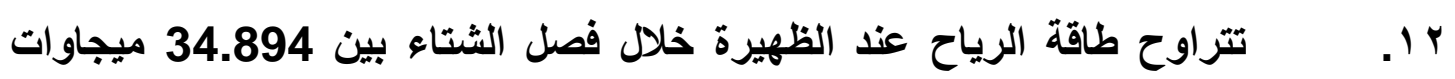

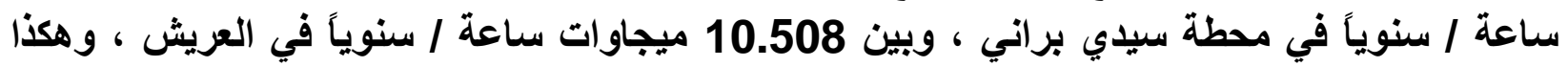

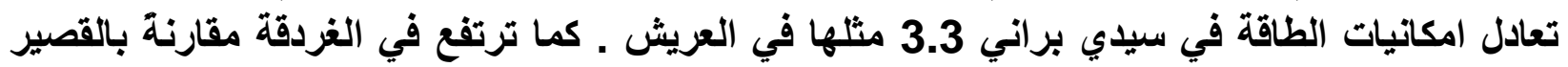

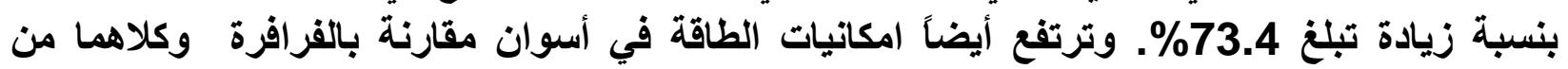

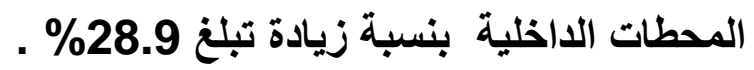

r ا. . عتبر امكانيات طاقة الرياح عند الظهيرة خلال فصل الربيع هي الأعلى بين

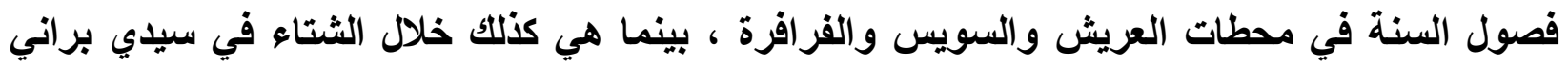
فقط ، وخلال الصيف في كلي من الغردقة وأسوان والأسكندرية . 


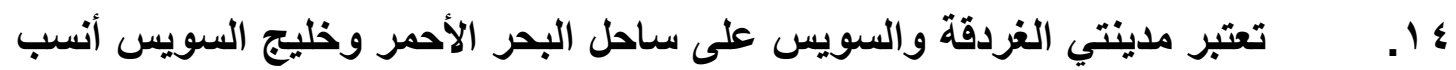

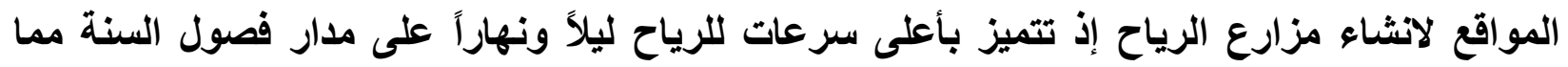

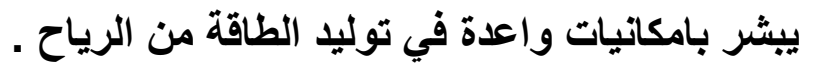

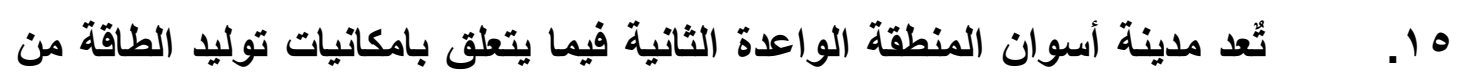

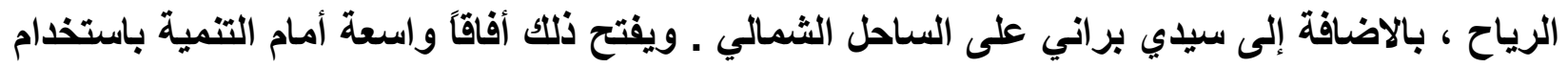

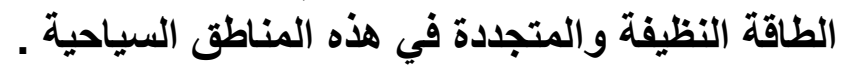

التوصيات :-

إجراء المزيد من الأبحاث الجغرافية فيما يتعلق بسرعة الرياح وامكانيات استخدامها في

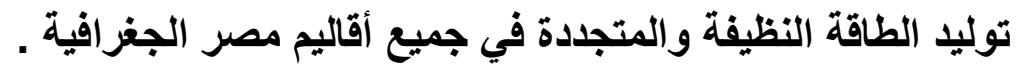

نشر الوعي البيئي بجدوى استخدام الطاقة النظيفة للحفاظ على سلامة البيئة وصحة

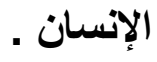

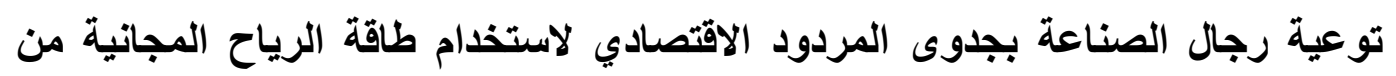

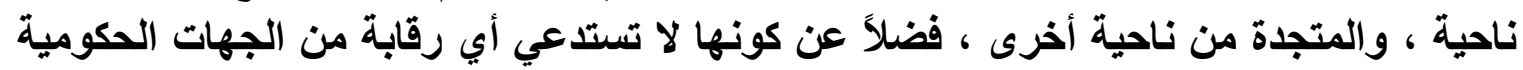

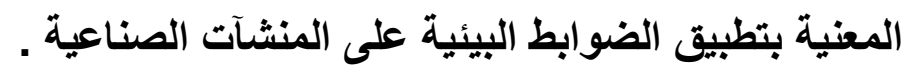

| الدقة في اختيار مواقع انشاء مزارع الرياح لتحقيق أعلى استفادة اقتصادية من ناحية ، ومراعاه

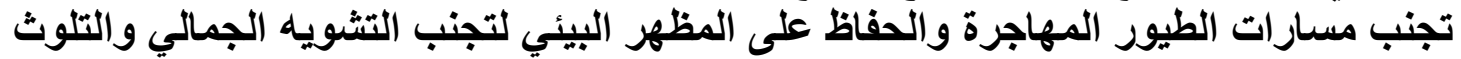

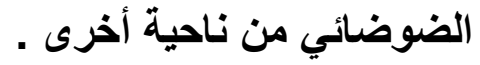

كلمات المفتاح: طاقة الرياح- توربينات الرياح ـ مزارع الرياح ـ شدة الرياح ـ 


\section{Wind Energy in Egypt \\ A Study in Applied Climatology}

\section{Abstract}

This study analyzes the characteristic of wind directions and wind velocity in Egypt. It depends on $\mathbf{3 3}$ meteorological stations in four regions in Egypt: Northern cost and Delta, Red Sea Cost, Nile Valley and West Desert, and Sinai during the period 1980 / 2004.

This research studies the wind hourly during the period1995/2004 . This study uses many equations to calculate Resultant Wind Velocity (V), Resultant Wind Run, Wind Power for different study stations.

This study aims to assume Renewable wind Energy in Egypt, and defined suitable region to establish wind farms and identify the descriptions of Wind Turbines .

Keywords: Renewable Energy, Resultant Wind Velocity , Resultant Wind Run, Wind Power, Wind Turbines , Wind energy, Egypt 